\title{
Granger-Causality in peripheral EMU public debt markets: A dynamic approach
}

\author{
Marta Gómez-Puiga, Simón Sosvilla-Rivero ${ }^{b^{*}}$ \\ ${ }^{a}$ Department of Economic Theory, Universitat de Barcelona. 08034 Barcelona, Spain \\ ${ }^{b}$ Department of Quantitative Economics, Universidad Complutense de Madrid. 28223 \\ Madrid, Spain
}

February 2013

\begin{abstract}
Our research aims to analyze the possible existence of Granger-causal relationships in the behavior of public debt issued by peripheral member countries of the European Economic and Monetary Union (EMU), with special emphasis on the recent episodes of crisis triggered in the eurozone sovereign debt markets since 2009. With this goal in mind, we make use of a database of daily frequency of yields on 10-year government bonds issued by five EMU countries (Greece, Ireland, Italy, Portugal and Spain), covering the entire history of the EMU from its inception on 1 January 1999 until 31 December 2010. In the first step, we explore the pair-wise Granger-causal relationship between yields, both for the whole sample and for changing subsamples of the data, in order to capture the possible time-varying causal relationship. This approach allows us to detect episodes of significant increase in Granger-causality between yields on bonds issued by different countries. In the second step, we study the determinants of these episodes, analyzing the role played by different factors, paying special attention to instruments that capture the total national debt (domestic and foreign) in each country.
\end{abstract}

Keywords: Sovereign bond yields, Granger-causality, time-varying approach, euro area, peripheral EMU countries.

JEL Classification Codes: E44, F36, G15

*Corresponding author. Tel.: +34 913942342; fax: +34 913942591.

E-mail addresses: marta.gomezpuig@ub.edu (M. Gómez-Puig), sosvilla@,ccee.ucm.es (S. SosvillaRivero) 


\section{Introduction}

After ten years of stability, the financial and economic crisis that followed the US subprime crisis and Lehman Brothers collapse highlighted the imbalances within the European Economic and Monetary Union (EMU) countries. These imbalances had probably been undervalued during the stability period when markets seemed to underestimate the possibility that governments might default. Nevertheless, from August 2007 onwards, in parallel with the rise in global financial instability that led to a "flight-to-quality", yield spreads of euro area issues with respect to Germany spiraled (see Figure 1). Moreover, since 2010, Greece has been bailed out twice and the Republic of Ireland and Portugal also needed bailouts to stay afloat. These events brought to light the fact that the origin of sovereign debt crises in Europe could even go beyond the imbalances in public finances.

Indeed, the main causes of the debt crises in Europe vary according to the country and reflect an important interconnection between public and private debt. In Ireland, the crisis was mainly due to the private sector, particularly a domestic housing boom which was financed by foreign borrowers who did not require a risk premium related to the probability of default (see Lane, 2011). In Spain, since absorption exceeded production, the external debt grew and the real exchange rate appreciated, implying a loss of competitiveness for the economy. Unlike previous expansions, the resort to financing was not led by the public sector but by private households and firms. In contrast to Ireland and Spain, the origin of the debt crisis in Greece and Portugal was the structural deficit in the government sector. If the crisis spreads to Italy, this structural deficit would be the possible cause. Greece and Italy's large fiscal deficit and huge public debt are the cumulative result of chronic macroeconomic imbalances ${ }^{1}$. However, the case of Portugal illustrates the importance of external debt ${ }^{2}$ (specifically, that of its private sector: banks and enterprises).

\footnotetext{
1 As pointed out in Gómez-Puig (2006 and 2008), in the past, Italy may have benefited from the fact that "size matters for liquidity" and thus for the success of a sovereign debt market since at the end of 2010 its market was the biggest in the euro area (see Table 6).

2 The current account deficit over GDP was $9.86 \%$ in December 2010.
} 
Some studies have already found a strong relationship between risk premium and a wide range of vulnerability indicators that go beyond the fiscal position. The IMF (2010) and Barrios et al. (2009) present empirical evidence of the strong relationship between current account deficits and foreign debt and the behavior of sovereign risk premium. Moreover, Gros (2011) contends that foreign debt is more important than public debt, and that this may have a number of implications for the ongoing eurozone crisis ${ }^{3}$.

Other authors (Bolton and Jeanne (2011) and Allen et al. (2011), to name a few), have focused on the study of cross-border banking system linkages to the government sector. Although, crossborder banking effect on risk diversification is a key benefit, foreign capital is likely to be more mobile than domestic capital and, in a crisis situation, foreign banks may simply decide to "cut and run". In addition, in an integrated banking system, financial or sovereign crisis in a country can quickly spill over to other countries. In this context, it is important to note that the European Union and, especially the euro area, witnessed a significant increase in cross-border financial activity over the ten years before the global crisis (see Barnes, Lane and Radziwill, 2010). Both the elimination of currency risk and regulatory convergence ${ }^{4}$ can explain this important increase (see Kalemli-Ozcan, Papaioannou and Peydró-Alcalde, 2009). Spiegel (2009a and 2009b) shows that the effect of the monetary union has been even stronger for some of the peripheral EMU countries. In particular, the sources of external financing for Portuguese and Greek banks radically shifted on joining the euro; traditionally reliant on dollar debt, these banks were subsequently able to raise funds from their counterparts elsewhere in the EMU.

Therefore, in this scenario of increased cross-border financial activity in the euro area, Gray et al. (2008) point out the importance of identifying the channels that connect the banking and the sovereign sectors, not only within a country but across countries as well. On the one hand, a

\footnotetext{
3 This author points out that the importance of external debt is due to the fact that euro area governments retain full sovereignty over the taxation of their citizens, but they are bound by existing treaties and international norms and do not have a free hand in taxing noncitizens. Therefore, euro countries can always service their domestic debt, even without access to the printing press, but not their external debt.

4 The introduction of the Single Banking License in 1989 through the Second Banking Directive was a decisive step towards a unified European financial market, which subsequently led to a convergence in financial legislation and regulation across member countries.
} 
systemic banking crisis can induce a contraction of the entire economy, weakening public finances and thus transferring the distress to the government. This effect is amplified when the financial sector has state guarantees. As a feedback effect, risk is further transmitted to holders of sovereign debt. On the other hand, macroeconomic imbalances in a specific country lead to rising sovereign spreads and a devaluation of the government debt that is mirrored in banks' balance sheets. Moreover, as the recent European sovereign debt crisis has stressed, transmission of the crisis in one country to others through the banking system can be a major issue.

The recent literature on sovereign debt has not studied these linkages in depth. Only a handful of recent papers have addressed the interaction between sovereign default and the stability of the domestic financial system. The analyses by Mody (2009), Ejsing and Lemke (2009), Gennaioli, Martin and Rossi (2010) and Broner, Martin and Ventura (2010), are among them ${ }^{5}$. The papers most closely related to our analysis are the studies by Bolton and Jeanne (2011) and Andenmatten and Brill (2011). Bolton and Jeanne's (2011) central issue is the analysis of the international contagion caused by the banks' exposure to the sovereign risk of foreign countries. To that end, they use data from the 2010 European stress test and show that financial integration without fiscal integration results in an inefficient equilibrium supply of government debt ${ }^{6}$. Andenmatten and Brill (2011) perform a bivariate test for contagion that is based on an approach proposed by Forbes and Rigobon (2002) to examine whether the co-movement of sovereign CDS premium increased significantly after the beginning of the Greek debt crisis in October 2009. Unlike Forbes and Rigobon, they conclude that in European countries "both contagion and interdependence" occurred.

However, an important constraint in the above-mentioned empirical evidence is the fact that it ignores the dynamic component of the degree of interconnection of public debt markets. In this

\footnotetext{
5 Beakert et al. (2011) analyze the transmission of crises to country-industry equity portfolios in 55 countries, using the $2007-2009$ financial crisis as a laboratory.

${ }^{6}$ The same conclusion is reached by Gros and Mayer (2011) who say that "The EU resembles a group of highly interdependent companies with large cross-holdings of equity stakes. However, the formal structure of the group is very light. There is no central authority that can give orders to individual members of the group". They conclude that the euro area can no longer avoid a stark choice: "either it sticks to the limited liability character of EMU (but in this case sovereign default becomes likely), or it moves towards a fiscal union with a mutual guarantee for the public debt of all member countries".
} 
regard, Abad, Chuliá and Gómez-Puig (2010 and 2012) examine the European government bond market integration from a dynamic perspective, applying an asset pricing model to a dataset spanning the years 2004 to $2009^{7}$. Nonetheless, the evolution of the time-varying degree of causality of EMU sovereign debt yields behavior (and the factors behind it, especially the role played by private debt and cross-border banking linkages) has not yet been analyzed in sufficient depth by the literature. This paper aims to carry out an analysis of this kind.

Thus, the main objectives of this paper are threefold: (1) to test for the existence of possible Granger-causal relationships between the evolution of the yield of bonds issued by peripheral EMU countries, (2) to examine the time-varying nature of these Granger-causal relationships and to detect episodes of significant intensification in causality between them, and (3) to analyze the determinants of those events considering not only macroeconomic imbalances, but also the role played by market liquidity, private debt, cross-border banking linkages, indicators of investor sentiment and global risk aversion. This paper also makes three main contributions to the existing literature. First, it presents a dynamic approach to the analysis of the evolution of the degree of Granger-causality of EMU sovereign debt yields behavior. Second, it makes use of a unique dataset on private debt-to-GDP by sector (households, banks and non-financial corporations) in each EMU country and on cross-border banking linkages. Private debt dataset has been built up by the authors using the Monetary Financial Institutions (MFI) balance sheet statistics provided for each euro country by the European Central Bank, whilst cross border banking linkages are measured using the consolidated claims on an immediate borrower basis of Bank for International Settlements reporting banks (in the public, the banking and the non-financial private sectors). Third, it focuses the analysis on peripheral EMU countries (Greece, Ireland, Italy, Portugal and Spain) since these are the countries which have come under market pressure since 2009, reflecting investors' perceptions of risks, and which to a large extent have been the origin of the current sovereign debt crisis in the whole eurozone.

\footnotetext{
7 Their results suggest that, from the beginning of the financial market tensions in August 2007, markets moved towards higher segmentation, and the differentiation of country risk factors increased substantially across countries. Although the levels were very low, the persistence of positive yield spreads against Germany detected before the beginning of the crisis (see Gómez-Puig, 2009a and 2009b) was still a reflection of incomplete integration in EMU bond markets.
} 
The most important results of the analysis can be summarized as follows. Firstly, we provide empirical evidence of the existence of sub-periods of Granger-causality in all pair-wise relationships. Secondly, we also present empirical evidence which indicates that the Grangercausality relationships between peripheral EMU yields have significantly increased during the recent crises in sovereign debt markets from 2009. Thirdly, the results of the Probit models estimated to analyze the determinants of the episodes of Granger-causality intensification show that in all cases the variable that captures cross-border banking linkages is statistically significant. This finding might suggest that, not only macroeconomic imbalances may be key determinants of the probability of occurrence of those episodes, but in a scenario of increased international financial activity in the euro area, transmission of the crisis in one country to other countries through the banking system can be a major issue. Lastly, the results support the important role played by private debt, especially in the cases of Ireland, Italy and Spain.

The rest of the paper is organized as follows. Section 2 presents the Granger-causality analysis and our approach for the detection of episodes of increase in Granger-causality. In Section 3 we carry out the exploration of the determinants of these episodes. Finally, Section 4 summarizes the findings and offers some concluding remarks.

\section{Granger-causality analysis}

\section{1. Econometric methodology}

The concept of Granger-causality was introduced by Granger (1969) and Sims (1972) and is widely used to ascertain the importance of the interaction between two series. The central notion is one of predictability (Hoover, 2001): one variable Granger-causes some other variable, given an information set, if past information about the former can improve the forecast of the latter based only in its own past information. Therefore, the knowledge of one series evolution reduces the forecast errors of the other, suggesting that the latter does not evolve independently of the former. 
Testing Granger causality typically employs the same lags for all variables. This poses a potential problem, since Granger-causality tests are sensitive to lag length. Therefore, it is important that the lengths selected should be the right ones to avoid inconsistently estimating the model and drawing misleading inferences (see, Thornton and Batten, 1985). In determining the optimal lag structure for each variable, we follow Hsiao's (1981) sequential method to test for causality, which combines Akaike's final predictive error (FPE, from now on) and the definition of Granger-causality ${ }^{8}$. Essentially, the FPE criterion trades off bias that arises from under-parameterization of a model against a loss in efficiency resulting from over-parameterization of the model, removing us from the ambiguities of the conventional procedure.

Consider the following models,

$$
\begin{gathered}
X_{\mathrm{t}}=\alpha_{0}+\sum_{i=1}^{m} \delta_{i} X_{t-i}+\varepsilon_{t} \\
X_{t}=\alpha_{0}+\sum_{i=1}^{m} \delta_{i} X_{t-i}+\sum_{j=1}^{n} \gamma_{j} Y_{t-j}+\varepsilon_{t}
\end{gathered}
$$

where $X_{t}$ and $Y_{t}$ are stationary variables [i.e., they are $\mathrm{I}(0)$ variables]. The following steps are used to apply Hsiao's procedure for testing Granger-causality:

i) Treat $X_{t}$ as a one-dimensional autoregressive process (1), and compute its FPE with the order of lags $m$ varying from 1 to $m^{9}$. Choose the order which yields the smallest FPE, say $m$, and denote the corresponding FPE as $\mathrm{FPE}_{\mathrm{X}}(\mathrm{m}, 0)$.

ii) Treat $X_{t}$ as a controlled variable with $m$ number of lags, and treat $Y_{t}$ as a manipulated variable as in (2). Compute again the FPE of (2) by varying the order of lags of $Y_{t}$ from 1 to $n$, and determine the order which gives the smallest FPE, say $n$, and denote the corresponding FPE as $\operatorname{FPE}_{\mathrm{X}}(\mathrm{m}, \mathrm{n})^{10}$.

\footnotetext{
${ }^{8}$ Thornton and Batten (1985) show that the Akaike's FPE criterion performs well relative to other statistical techniques.

${ }^{9} \mathrm{FPEx}(\mathrm{m}, 0)$ is computed using the formula: $\operatorname{FPE}_{X}(m, 0)=\frac{T+m+1}{T-m-1} \cdot \frac{S S R}{T}$, where $\mathrm{T}$ is the total number of observations and SSR is the sum of squared residuals of OLS regression (1)

${ }^{10} \mathrm{FPE}_{\mathrm{X}}(\mathrm{m}, \mathrm{n})$ is computed using the formula: $\operatorname{FPE}_{X}(m, n)=\frac{T+m+n+1}{T-m-n-1} \cdot \frac{S S R}{T}$, where $\mathrm{T}$ is the total number of observations and SSR is the sum of squared residuals of OLS regression (2)
} 
iii) Compare $\operatorname{FPE}_{\mathrm{X}}(\mathrm{m}, 0)$ with $\mathrm{FPE}_{\mathrm{X}}(\mathrm{m}, \mathrm{n})$ [i.e., compare the smallest FPE in step (i) with the smallest FPE in step (ii)]. If $\operatorname{FPE}_{\mathrm{X}}(\mathrm{m}, 0)>\mathrm{FPE}_{\mathrm{X}}(\mathrm{m}, \mathrm{n})$, then $Y_{t}$ is said to cause $X_{t}$. If $\mathrm{FPE}_{\mathrm{X}}$ $(\mathrm{m}, 0)<\mathrm{FPE}_{\mathrm{X}}(\mathrm{m}, \mathrm{n})$, then $X_{t}$ is an independent process.

iv) Repeat steps i) to iii) for the $Y_{t}$ variable, treating $X_{t}$ as the manipulated variable.

When $X_{t}$ and $Y_{t}$ are not stationary variables, but are first-difference stationary [i.e., they are I(1) variables] and cointegrated (see Dolado et al., 1990), it is possible to investigate the existence of a Granger-causal relationships from $\Delta X_{t}$ to $\Delta Y_{t}$ and from $\Delta Y_{t}$ to $\Delta X_{t}$, using the following error correction models:

$$
\begin{gathered}
\Delta X_{t}=\alpha_{0}+\sum_{i=1}^{m} \delta_{i} \Delta X_{t-i}+\varepsilon_{t} \\
\Delta X_{t}=\alpha_{0}+\beta Z_{t-1}+\sum_{i=1}^{m} \delta_{i} \Delta X_{t-i}+\sum_{j=1}^{n} \gamma_{j} \Delta Y_{t-j}+\varepsilon_{t}
\end{gathered}
$$

where $Z_{t}$ is the OLS residual of the cointegrating regression $\left(X_{t}=\mu+\lambda Y_{t}\right)$, known as the errorcorrection term. Note that, if $X_{t}$ and $Y_{t}$ are I (1) variables, but they are not cointegrated, then $\beta$ in (4) is assumed to be equal to zero.

In both cases [i.e., $X_{t}$ and $Y_{t}$ are $\mathrm{I}(1)$ variables, and they are or are not cointegrated], we can use Hsiao's sequential procedure substituting $X_{t}$ with $\Delta X_{t}$ and $Y_{t}$ with $\Delta Y_{t}$ in steps i) to iv), as well as substituting expressions (1) and (2) with equations (3) and (4). Proceeding in this way, we ensure efficiency since the system is congruent and encompassing (Hendry and Mizon, 1999).

\section{2. Data}

We use daily data of 10-year bond yields from 1 January 1999 to 31 December 2010 collected from Thomson Reuters Datastream for EMU peripheral countries: Greece, Ireland, Italy, Portugal and Spain. Figures $1 \mathrm{a}$ and $1 \mathrm{~b}$ plot the evolution of daily 10 -year sovereign bond yields and their spread 
against the bund for each country in our sample. A simple look at these figures indicates the differences in the yields behavior before and after the financial crisis of 2008.

[Insert Figures 1a and 1b here]

Specifically, it is remarkable that after the introduction of the euro in January 1999 and until the subprime crisis in global financial markets in August 2007, spreads on bonds of EMU peripheral countries moved in a narrow range with only slight differentiation across countries. In fact, the stability and convergence of spreads was considered a hallmark of successful financial integration inside the euro area. Nevertheless, after the subprime crisis in 2007, severe tensions emerged in financial markets worldwide, including the EMU bond market. Moreover, following the collapse of the US financial institution Lehman Brothers on 15 September 2008, the financial turmoil turned into a global financial crisis which began to spread to the real sector.

Therefore, the financial crisis highlighted the imbalances within the euro area and yield spreads between government bond issues of participating countries, which had reached levels close to zero between 2003 and 2007 (the average value of the 10-year yield spread against the German bund moved between -4 and 20 basis points, in the case of Ireland and Greece, respectively), reemerged. Indeed, the risk premium on EMU government bonds increased strongly in 2008, reflecting investor perceptions of upcoming risks. Concretely, Figure $1 \mathrm{~b}$ displays that by the end of December 2010 it reached levels of 952 basis points in Greece, 580 in Ireland, 380 in Portugal, 255 in Spain and 182 in Italy.

\section{[Insert Table 1 here]}

Table 1 presents descriptive statistics for the levels and differences of the 10-year government's yield in peripheral EMU countries during the sample period (1999-2010). As can be seen, the mean is not significantly different from zero for the first differences. Normality is tested with the Jarque- 
Bera test (which is distributed as $\chi^{2}(2)$ under the null) and strongly rejected for both the levels and first differences. Since rejection could be due to either excess of kurtosis or skewness, we report these statistics separately in Table 1. Given that the kurtosis of the normal distribution is 3, our results suggest that the distribution of the yields of Greece and Ireland, as well as all the first differences, are peaked relative to the normal, while the distribution of the yields in the cases of Italy, Portugal and Spain are flat relative to the normal. Finally, regarding the asymmetry of the distribution of the series around their mean, we find positive skewness for all the variables in levels and for the first difference in the case of Italy, suggesting that their distributions have long right tails, whilst in the cases of the first differences of yields for Greece, Ireland, Portugal and Spain there is evidence of negative skewness and therefore of distributions with long left tails.

\subsection{Preliminary results}

As a first step, we tested for the order of integration of the 10 -year bond yields by means of the Augmented Dickey-Fuller (ADF) tests. The results, shown in Table 2, decisively reject the null hypothesis of non stationarity, suggesting that both variables can be treated as first-difference stationary ${ }^{11}$.

\section{[Insert Table 2 here]}

Following Carrion-i-Silvestre et al. (2001)'s suggestion, we confirm this result using the Kwiatkowski et al. (1992) (KPSS) tests, where the null is a stationary process against the alternative of a unit root. As can be seen in Table 3, the results fail to reject the null hypothesis of stationarity in first differences, but strongly reject it in levels.

$$
\text { [Insert Table } 3 \text { here] }
$$

\footnotetext{
11 These results were confirmed using Phillips-Perron (1998) unit root tests controlling for serial correlation and the Elliott, Rothenberg, and Stock (1996) Point Optimal and Ng and Perron (2001) unit root tests for testing non-stationarity against the alternative of high persistence. These additional results are not shown here to save space, but they are available from the authors upon request.
} 
As a second step, we tested for cointegration between each of the 10 pair combinations ${ }^{12}$ of peripheral EMU yields using Johansen $(1991,1995)$ 's approach. An important decision in this approach is whether to include deterministic terms in the cointegrating Vector Autoregressive (VAR) model. Deterministic terms, such as the intercept, linear trend, and indicator variables, play a crucial role in both data behavior and limiting distributions of estimators and tests in integrated processes. Banerjee et al. (1993), Johansen (1994) and Nielsen and Rahbek (2000) show that the statistical properties of the commonly used test procedure are affected, indicating that in some cases its size cannot be controlled, and that in others there is substantial power loss. Depending on their presence or absence, the system may manifest drift, linear trends in cointegration vectors, or even quadratic trends. In practical work, there seem to be only two relevant model representations for the analysis of cointegration amongst most economic time series variables:

i. the level data have no deterministic trend and the cointegrating equations have intercepts; and

ii. the level and the cointegrating equations have linear trends.

Table 1 shows that the hypothesis of the expected values of the first differences of the series is equal to zero cannot be rejected; hence, there is no evidence of linear deterministic trends in the data. The graphs in Figure 1a support this finding. Therefore, we conclude that the cointegrated VAR model should be formulated according to i), with the constant term restricted to the cointegration space, and no deterministic trend terms. This implies that some equilibrium means are different from zero.

As can be seen in Table 4, only for the Greece-Ireland and Greece-Portugal cases do the trace test indicate the existence of one cointegrating equation at (at least) the 0.05 level. Therefore, for these two pairs we test for Granger-causality in first differences of the variables, with an error-correction term added [i. e., equations (3) and (4)], whereas for the remaining cases, we test for Granger-

\footnotetext{
${ }^{12}$ Recall that the number of possible pairs between our sample of five peripheral EMU yields is given by the following formula $\frac{n !}{r !(n-r) !}=\frac{5 !}{2 !(5-2) !}=10$.
} 
causality in first differences of the variables, with no error-correction term added [i. e., equations (3) and (4) with $\beta=0$ ]

\author{
[Insert Table 4 here]
}

\title{
2.4. Empirical results
}

The resulting FPE statistics for the whole sample are reported in Table $5 .{ }^{13}$

[Insert Table 5 here]

As can be seen, in most of the cases our results suggest bidirectional Granger-causality. We do not find unidirectional Granger-causality relationships running from Greece to Spain, from Italy to Ireland or from Portugal to Ireland.

Note that, even though the results of the cointegration tests reject (with only two exceptions) a long-run relationship between them, we find evidence of strong Granger-causal linkages between peripheral EMU yields. Therefore, each yield series contains useful information that is not present in the others which can help to explain the others' short-run evolution.

In order to gain further insights into the dynamic Granger-causality between the 20 possible relationships in peripheral EMU yields, we carry out 33,486 rolling regressions using a window of 200 observations ${ }^{14}$. In each estimation, we apply Hsiao (1981)'s sequential procedure outlined above to determine the optimum $\operatorname{FPE}(\mathrm{m}, 0)$ and $\mathrm{FPE}(\mathrm{m}, \mathrm{n})$ statistics in each case.

\footnotetext{
13 These results were confirmed using both Wald statistics to test the joint hypothesis $\hat{\gamma}_{1}=\hat{\gamma}_{2}=\ldots=\hat{\gamma}_{n}=0$ in equation (4) and Williams-Kloot test for forecasting accuracy (Williams, 1959). These additional results are not shown here to save space, but they are available from the authors upon request.

14 To the best of our knowledge, there is no statistical method to set the optimal window size. The chosen value of 200 observations is representative of the one used in practice and seems appropriate for our empirical application since it represents $6.36 \%$ of the sample. We have also used a value of 100 observations. The results (not shown here to save space, but they are available from the authors upon request.) render the same qualitative conclusions than in the case of using 200 observations.
} 
A graphic presentation of the evolution of the difference between FPE $(m, 0)$ and FPE $(m, n)$ statistics in each case is shown in Figure 2. Concretely, Figure 2a to Figure 2e present the FPE sequence from rolling regressions running from Greece, Ireland, Italy, Portugal and Spain, respectively. Therefore, these graphs provide us with a view of the dynamic influence of each EMU peripheral yield over the other four and constitute our indicator of time-varying Granger-causality. Adopting a forward-looking framework, we assign the computed indicator to the first date used in the rolling regressions. Therefore, the sample covers the period 1 January 1999 to 26 March 2010 in all cases, except in those pairs where Greece is present, in which case the sample runs from 1 January 2001 to 26 March 2010. Note that if the difference is positive in the case XX $\rightarrow$ YY, this indicates the existence of a statistically significant Granger-causality relationship running from country XX towards country YY.

As can be seen, we find sub-periods of Granger-causality in all pair-wise relationships, including those running from Greece to Spain, from Italy to Ireland and Portugal to Ireland, even though these relationships were rejected when we performed the tests for the whole sample. In other words, we detect, in all cases, sub-periods where the yields on bonds issued by one peripheral EMU country carries relevant and useful information about the future behaviour of the yields on bonds issued by other peripheral EMU country.

We proceed further by identifying sub-periods of significant increase in Granger-causality in order to be able to analyze which factors may have been behind them. To that aim, we identify episodes of Granger-causality intensification as those in which the time-varying Granger-causality indicator is greater than its average plus two standard errors ${ }^{15}$. Therefore, we look for episodes where there is evidence of an enlargement in the information content of the yield series to significantly improve the explanatory power of future evolution of the other yield series, suggesting a strengthening of their interdependence.

\footnotetext{
15 We perform formal tests to evaluate whether the series have the same mean during the detected episodes and the rest of the observations. The results of these tests (not shown here, but available from the authors upon request) strongly reject the null hypothesis of equal mean across sub-samples, and provide additional support for the presence of increased Granger-causality.
} 
The graphs in Figure 2 suggest that these episodes are concentrated around the first year of the existence of the EMU in 1999, the introduction of euro coins and banknotes in 2002, and the global financial crisis of the late-2000s. As can be seen, the graphs also indicate that the Grangercausality relationships between peripheral EMU yields increased significantly during the recent crises in sovereign debt markets since 2009, providing evidence of a reinforcement of the interconnection between them.

[Insert Figure 2 here]

\section{Determinants of episodes of Granger-causality intensification}

\subsection{Econometric methodology}

Once the episodes of Granger-causality intensification have been detected, we use Probit models to analyze their determinants. In our case, we define a new dependent variable $(y)$ that takes the value one if we have detected such episode and zero otherwise. The goal is to quantify the relationship between a set of instruments $(X)$ characterizing the two countries involved in an episode of Granger-causality intensification and the probability of occurrence of such event $(y)$.

To this end, we adopt a specification designed to handle the particular requirements of binary dependent variables. Suppose that we model the probability of observing a value of one as:

$$
\operatorname{Pr}(y=1 \mid X, \beta)=1-\Phi\left(-X^{\prime} \beta\right)=\Phi\left(X^{\prime} \beta\right)
$$

where $\Phi$ is the cumulative distribution function of the standard normal distribution. As can be seen, we adopt the standard simplifying convention of assuming that the index specification is linear in the parameters so that it takes the form $X^{\prime} \beta$.

\subsection{Instruments to model the Granger-causality intensification}

According to Dornbusch, Park, and Claessens (2000), reasons that may explain the evolution of yield's Granger-causality between countries can be divided into two groups: fundamental-based reasons on the one hand, and investor behavior-based reasons on the other. While fundamental- 
based transmission works through real and financial linkages across countries, behavior-based is more sentiment-driven. Therefore, in our analysis we will use instruments that capture both of them. Following the literature, in order to measure fundamental reasons, we not only use instruments that gauge each country's component of risk, but also instruments that asses the global component of risk. To that end, on the one hand, we use instruments that capture the country's fiscal position, the market liquidity in each country, the foreign debt, the country's potential rate of growth, the loss of competitiveness, the private sector indebtedness and, especially the cross-border banking system linkages. And on the other hand, we use an indicator of global risk aversion.

Concretely, the variables used to measure the country's fiscal position are the government debt-toGDP (GOVDEB) and the government deficit-to-GDP (DEF). These two variables have been widely used in the literature by other authors (see, e.g., Bayoumi et al., 1995) and present the advantage over the credit rating that they cannot be considered ex post measures of fiscal sustainability. Since they are measures of credit risk, they should be directly related to the probability of Granger-causality intensification. They are compiled from Eurostat, and monthly data are linearly interpolated from quarterly observations.

Regarding liquidity premium in each sovereign debt market, empirical papers examining the influence of market liquidity in bond markets use different measures to gauge its three main dimensions (tightness, depth and resiliency): trading volume; bid-ask spreads; the outstanding amount of debt securities; or the issue size of the specific bond. However, several studies have shown that all liquidity measures are closely related to each other (Korajczyk and Sadka (2008), Gómez-Puig(2006) and Gerlach et al. (2010) to name a few).

\section{[Insert Table 6 here]}

Moreover, Table 6 shows that very important size differences can be observed among peripheral euro-area debt markets in our sample period. Concretely, at the end of 2010, the Italian market, 
with a market share of $24.1 \%$ (surpassing the German market), was the biggest in the euro-area; the Spanish and the Greek market accounted, respectively, for $9.3 \%$ and $4.5 \%$ of the total; whilst the Portuguese and the Irish were very small markets (they only accounted for $2.2 \%$ and $1.5 \%$ of the total). Therefore, given (i) the empirical evidence that suggest that there is a common component among different measures of liquidity and (ii) the large size differences observed between EMU peripheral sovereign debt markets, it is likely that the overall outstanding volume of sovereign debt (which is considered a measure of market depth because larger markets may present lower information costs since their securities are likely to trade frequently, and a relative large number of investors may own or may have analyzed their features) might be a good proxy of liquidity differences among markets. Indeed, some literature supports the importance of market size in the success of a debt market ${ }^{16}$. Nevertheless, there is another reason to choose this variable: it might capture an additional benefit of large markets to the extent that the "too big to fail theory" $(\text { TFTF })^{17}$, taken from the banking system, might also hold in sovereign debt markets. The overall outstanding amounts of public debt data (LIQ) have been taken from the Bank for International Settlements and monthly data have been interpolated from quarterly observations. Since liquidity premium decreases with market size, we would expect a positive effect of this variable on the probability of a rise in causality among yields of countries that present small and medium debt markets' size (Ireland, Portugal, Greece and Spain), and a negative effect in the relationships where Italy is involved since its large market size may have benefited this country twice: (a) its liquidity premium would be smaller and (b) according to the TBTF theory its large market size might have preserved this debt market from excessive turbulent speculative attacks.

Besides, the current-account-balance-to-GDP ratio (CAC) is the instrument used as a proxy of the foreign debt and the net position of the country towards the rest of the world. Note that CAC is

\footnotetext{
16 McCauley and Remolona (2000) note that if substantial fixed costs are involved in the production of information about the future path of interest rates, the size of the whole debt market matters. They calculate that there may be a size threshold around $\$ 100-200$ billions, below which sustaining a liquid government market may not be easy. Among peripheral EMU countries, Table 6 shows that two countries were below this threshold: Ireland and Portugal. Economides and Siow (1988) point out that there may be a trade-off between liquidity and market size. The smaller the debt market, the more difficult it will be for investors to process and evaluate information about securities and the higher the transaction costs and the liquidity premium. Finally, Gómez-Puig (2006) presents empirical evidence that supports the idea that after the removal of the exchange rate risk in 1999, in the context of increased competition among euro-area government securities' markets, their success might have been limited by the extent of their liquidity and market size.

17 Goodhart and Huang (2005) develop a model of the lender of last resort from a Central Bank viewpoint. Consistent with the TBTF theory, their model suggests that the Central Bank will only rescue banks which are above a threshold size.
} 
defined as the difference between exports and imports. Therefore an increase in CAC would signal an improvement in the net position of the country towards the rest of the world, reducing the probability of Granger-causality intensification in pair-wise relationships. The importance of this variable has been underlined by the IMF (2010) and Barrios et al. (2009). This variable is drawn from the OECD and monthly data are linearly interpolated from quarterly observations. In view of Mody (2009)'s argument that countries' sensitivity to the financial crisis is more pronounced the greater the loss of growth potential and competitiveness, we include instruments that measure these features. The unemployment rate $(\mathrm{U})$, which has been collected from Eurostat, is the variable used to capture the country's growth potential, whilst the Harmonized Index of Consumer Prices monthly interannual rate of growth (which has also been drawn from Eurostat) is the inflation rate measure (INF) we use as a proxy of the appreciation of the real exchange rate and, thus, the country's loss of competitiveness. An increase in both the unemployment rate $(U)$ or the inflation rate (INF) represents a deterioration of growth potential and competitiveness; so, it will augment the probability of occurrence of a Granger-causality intensification episode.

To assess the interconnection between the public and private debt and the role of the latter in the euro area sovereign debt crisis, we also incorporate instruments that capture the level of indebtedness of each country's private sector in the analysis. To that end, we make use of a unique dataset on private debt-to-GDP by sector (households, banks and non-financial corporations) in each EMU country. In particular, we use three variables: Banks' debt-to-GDP (BANDEB), nonfinancial corporations' debt-to-GDP (NFIDEB), and households' debt-to-GDP (HOUDEB), which have been constructed with data obtained from the European Central Bank Statistics. Since high leverage levels in the private sector have a negative impact in the public sector's sustainability, an increase in these three variables would affect positively to the probability of Granger-causality intensification. A summary of their evolution is presented in Table 7. Concretely, we have used the statistics corresponding to the Monetary Financial Institutions (MFI) balance sheets in each euro country. Thus, household debt corresponds to the total loans to households from MFIs. To isolate it from the intermediation effect that would inflate debt ratios, banks' debt is constructed by 
subtracting M3, banks' remaining liabilities and banks' capital and reserves from total MFI liabilities ${ }^{18}$. And non-financial corporation debt is built up by adding non-financial corporation securities to total loans to non-financial corporations from MFIs ${ }^{19}$.

\section{[Insert Table 7 here]}

Table 7 clearly shows the importance of private debt in the ongoing crisis. Concretely, after the subprime crisis in August 2007, not only does the government level of indebtedness increase in the euro area (the ratio over the GDP achieves levels of $143 \%, 119 \%, 96 \%, 93 \%$ and $60 \%$ at the end of December 2010 in Greece, Italy, Ireland, Portugal and Spain, respectively) but private borrowing also registers a sizeable increase. In particular, as can be observed, at the end of 2010, banks' debtto-GDP is huge in Ireland (729\%), but is also high in Portugal, Spain and Greece $(182 \%, 159 \%$ and 98\%). On the other hand, households' debt-to-GDP surpasses the $80 \%$ threshold in Ireland, Portugal and Spain, whilst non-financial corporations' debt-to-GDP is close to $90 \%$ in Portugal and Spain and around 70\% in Ireland. Thus, during the period 2007-2010, whereas the government debt-to-GDP ratio registers the highest increases compared to the period 2002-2006 in Ireland, Portugal and Greece $(39 \%, 15 \%$ and $9 \%)$, there is a much steeper rise in the banks' debt-to-GDP ratio which is higher than $150 \%$ in Greece, close to $70 \%$ in Ireland, around $64 \%$ in Spain and close to $40 \%$ in Portugal. Besides, households' debt-to-GDP ratio registers an increase close to $30 \%$ in Greece, close to $20 \%$ in Ireland and Spain and around 15\% in Italy, whilst non-financial corporations' debt-to-GDP ratio rises close to 30\%, 25\% and 20\% in Ireland, Spain and Greece respectively.

As it has already been mentioned, some authors (Bolton and Jeanne (2011) and Allen et al. (2011) among them) outline that, in an scenario of increased international financial activity in the euro

\footnotetext{
18 The banks' debt variable we have constructed avoids the effects of intermediation, even though it can only be considered as an approximation of its real value, and some caveats are in order: specifically, some deposits will appear as debt (those not included in M3) and some debt securities will not be considered debt (those included in M3).

19 Non-financial corporations' (NFCs) debt should also include "net equity of households" (liabilities of NFCs from direct pension commitments to their employees). Nevertheless, we have ignored this variable since it was not available for all the countries in the sample.
} 
area, not only public finances imbalances are key determinants of the probability that the sovereign debt crisis could spill over from one country to another, but that transmission of the crisis through the banking system can also be a major issue. Therefore, in our analysis we also include variables that capture the important cross-border banking system linkages in euro area countries, which might influence positively the probability of occurrence of a causality intensification episode. These linkages are measured using the consolidated claims on an immediate borrower basis of Bank for International Settlements (BIS) reporting banks in the public, banking and non-financial private sectors as a proportion of GDP (monthly data are linearly interpolated from quarterly observations). In particular, we include foreign bank claims on government debt-to-GDP (PUB), on bank debt-to-GDP (BAN) and on non-financial private sector debt-to-GDP (PRI). The evolution of these variables is summarized in Table 8.

\section{[nsert Table 8 here]}

The figures in Table 8 underline the fact that, as it was mentioned in the Introduction, the causes of the debt crises that led to subsequent rescues in Europe varied substantially according to country. Greek fiscal deficit and public debt to GDP were close to 15\% and 130\% at the end of 2009 as a result of chronic macroeconomic imbalances. Besides, on average, foreign banks' claims on its public sector debt represented around 30\% of its GDP during the period 2005-2010. Conversely, in Ireland, the crisis was mainly due to the private sector, particularly the domestic housing boom which was financed by foreign borrowing. In particular, the amount of bank and non-financial enterprise debt claimed by foreign banks is huge during the period 2005-2010 (102\% and 216\% of its GDP, on average). Finally, in Portugal, markets were mostly worried about the country's high external debt, specifically, that of its non-financial corporations. During the 2005-2010 period, foreign banks' claims on Portuguese enterprises surpassed 40\% of the country's GDP.

Moreover, we also explore the role of consolidated claims on an immediate borrower basis provided by BIS by nationality of reporting banks as a proportion of total foreign claims on each 
country. This variable is denoted as XXYYBAN, meaning the percentage of the total foreign claims on country XX held by country YY's banks (again, monthly data have been linearly interpolated from quarterly observations). We expect that higher banking sector exposure would be associated with higher probability of observing an episode of increased pair-wise Granger-causality.

\section{[Insert Table 9 here]}

This information is displayed in Table 9 and is very useful for understanding the channels of transmission of debt crises through the banking system. It can be observed that at the end of 2010 French and German banks were the most exposed to foreign Greek debt, holding 39.6\% and $23.7 \%$ of total foreign Greek claims respectively. In the case of Ireland, the maximum risk was borne by British banks (29.9\%) followed by the Germans (26.13\%). A Portuguese default would be especially harmful for Spanish banks which hold $41.9 \%$ of Portuguese banks' total claims. Finally, around $45 \%$ and close to $65 \%$ of Spanish and Italian foreign claims, respectively, are held by French and German banks.

As mentioned, we also introduce an instrument that might capture investor behavior-based reasons of crisis's transmission. We use the credit rating as a proxy of the default risk (RAT). Standard \&Poor's, Moody's and Fitch ratings for each government's debt are compiled from Bloomberg. Following Blanco (2001), we build up a scale to gauge the effect of investor sentiment based on the rating offered by the three agencies ${ }^{20}$. Since this variable is considered an expost measure of fiscal sustainability it should have a positive impact on the probability of occurrence of a causality intensification episode.

Moreover, several studies show that sovereign bond yields are not only driven by country-specific risk factors but that they are also significantly affected by global risk factors (see Codogno et al. (2003), Sgherri and Zoli (2009), Bernoth and Erdogan (2012) among them). These global risk

\footnotetext{
${ }^{20}$ By construction, the higher the scale, the worse the rating categories.
} 
factors reflect global investors' risk aversion, since in times of uncertainty, they become more risk averse and the "flight-to-safety" motive favors bonds of countries that are generally regarded to have a low default risk. Therefore, an increase in the Granger-causality of bond yields might also reflect a general increase in investors' risk aversion which might drive the yields of the peripheral countries simultaneously ${ }^{21}$. To measure risk aversion in financial markets, we rely on the Chicago Board Options Exchange Market Volatility Index (VIX), used by Bloom (2009) to capture uncertainty $^{22}$ (this variable is denoted as RISK) ${ }^{23}$.

Appendix 1 offers a summary of the explanatory variables used in the empirical analysis as well as the data sources.

\subsection{Empirical results}

Given that the instruments used as independent variables have been constructed on a monthly frequency, we also need to compute the dependent variable in the Probit models on a monthly basis. To do so, we first assign a value of 1 to the daily observation if the time-varying Grangercausality indicator is greater than its average plus two standard errors. In the second step, we compute the monthly data by averaging the daily observation and assigning a value of 1 if the resulting monthly average is greater than 0.5 (i. e., if at least for half of the month there is evidence of Granger-causality intensification).

We follow the general to specific approach characteristic of the London School of Economics based on the theory of reduction (Hendry, 1995, ch. 9). Therefore, our empirical analysis starts with a general statistical model that captures the essential characteristics of the underlying dataset, reducing the complexity of this general model by eliminating statistically insignificant variables,

\footnotetext{
21 We are very grateful to an anonymous referee for suggesting us this additional determinant factor.

22 The VIX represents the option-implied expected volatility on the S\&P500 index with a horizon of 30 calendar days. In the empirical analysis, we use end-of-month VIX levels. As pointed out by Bekaert et al. (2012), the link of VIX to option prices means it also harbours information about risk and risk aversion.

23 Besides, the interaction effects between the global risk indicator and both the liquidity measure and public and private debt-to-GDP in each country have also been tested. The results, not reported here to save space but available from the authors upon request, suggest that (except for Italy) the effect of an increase in global risk aversion on the probability of Granger-causality intensification in pair-wise relationships is magnified by market liquidity conditions. Regarding the interaction between global risk aversion and debt, our findings indicate that the incidence of an increase in Governments', Banks', Non-financial corporations' or Households' debt on the probability of Granger-causality intensification in peripheral EMU sovereign yields behavior is amplified in a context of high global risk aversion.
} 
checking the validity of the reductions at every stage to ensure congruence of the finally selected model. In Table 10 we report the final results of the Probit models estimated by maximum likelihood for the sample period March 2005 to March 201024,25,26. The z-statistics in that table are based on robust standard errors computed using the Huber-White quasi-maximum likelihood method. Following the same criterion that we used in Figure 2, Table 10a to 10e display the results of the Probit models estimated for the causal relationship running from Greece, Ireland, Italy, Portugal and Spain, respectively.

\section{[Insert Table 10 here]}

In binary models, estimated coefficients cannot be interpreted as the marginal effect on the dependent variable. Therefore, to gain further insights in the influence of the explanatory variables, in Table 10 we also show the associated marginal effects to compare their relative impacts. These marginal effects measure the influence of a unit change in a given explanatory variable on the probability of pair-wise Granger-causality intensification, holding all the other variables constant, and have been computed at their average values ${ }^{27}$.

As expected, our results indicate that the variables used to measure the country's fiscal position (GOVDEB and DEF) are important determinants of the probability of an episode of Grangercausality's increase. Specifically, regarding the variable that measures the government deficit (DEF),

\footnotetext{
24 Note that even though we could be dealing with a binary choice model with I(1) regressors, Park and Phillips (2000) have proved that the coefficient estimated by maximum likelihood are still consistent, converging at a rate $T^{3 / 4}$ along its principal component, having a slower rate of $T^{314}$ convergence in all other directions. Moreover, this authors showed that the limit distribution of the maximum likelihood estimator was mixed normal with mixing variates being dependent upon Brownian local time as well as Brownian motion, so the usual inference methods are still valid Grabowski (2007) have added that when among the regressors include variables with different orders of integration, the rate of convergence of the estimate of the coefficients depend of such order: $T^{314}$ for stationary regressors and $T^{314}$ for $\mathrm{I}(1)$ or $\mathrm{I}(2)$ regressors.

25 The reduction in the sample period is imposed by the availability of data regarding the consolidated claims of Bank for International Settlements' reporting banks on each sector.

26 The results are very similar for Logit models run on the same data.

27 Nevertheless, the direction of the effect of a change in any instrument depends only on the sign of the coefficient estimated: positive values imply that an increase in a given instrument will raise the probability of an increase in pair-wise Granger causality, while negative values indicate the opposite.
} 
it is statistically significant in the four relationships that run from Ireland, Italy and Portugal (see Table 10b, 10c and 10d) and in two out of the four relationships running from Spain (see Table 10e), whilst the variable that captures the government debt (GOVDEB) is always significant in the causal relationships running from Greece (see Table 10a), in two out of the four relationships running from Ireland and Spain (see Table 10b and Table 10e), in three of the relationships that run from Italy (see Table 10c) and in one relationship running from Portugal (see Table 10d). The marginal effects of DEF in the relationship that runs from Portugal to Spain and of GOVDEB in the relationship running Greece to Italy are particularly high (0.6197 and 0.5922 , respectively), stressing the role of the variables that gauge the country's fiscal position in the occurrence of episodes of pair-wise Granger-causality intensification from Greece and Portugal (as mentioned in the Introduction, in these two countries, the origin of the sovereign debt crisis were precisely the structural fiscal imbalances).

However, our results also indicate that other factors beyond the fiscal position do help to explain the episodes of Granger-causality intensification in peripheral EMU public debt markets. Notably, three variables are statistically significant in all cases: XXYYBAN, LIQ, and RISK.

The significance of XXYYBAN suggests that, in a scenario of increased cross-border financial activity in the euro area, transmission of the crisis in one country to other countries through the banking system can really be a major issue. Moreover, its marginal effect is especially high in the relationships running from Greece, Italy and Portugal, ranging from 0.3174 to 0.7940 (see Table 10a, Table 10c and Table 10d, respectively), therefore indicating that a unit increase from mean values of these variables notably increase the probability of pair-wise Granger-causality intensification.

On the other hand, we find a positive and significant sign for the variable LIQ in the relationships where Italy is not involved; whilst in all other causal relationships where Italy is involved, the variable LIQ presents a statistically significant negative sign. Consistent with our expectations, these 
results suggest that liquidity premium decreases with debt market size. Therefore, Italy may have benefited from the fact that "size matters for liquidity", and thus for the success of a sovereign debt market, since at the end of 2010 its market was the biggest in the euro area ${ }^{28}$. Nevertheless, we would like to note that the marginal effect of the variable LIQ is very small in all cases, therefore indicating that a unit increase from mean values in these variables only marginally affects the probability of pair-wise Granger-causality intensification.

Finally, the significance of the variable RISK could be interpreted as evidence supporting the view that an increase in investors' risk aversion boosts transmission of the crisis since the "flight-tosafety" motive benefits bonds issued by countries that are generally regarded to have a low default risk. The marginal effect of this variable is particularly high in the relationships running from Greece and Spain (see Table 10a and 10e, respectively) and in explaining the causal relationships from Italy and Portugal to Spain (see Table 10c and 10d, respectively), suggesting that the riskier the environment, the more likely is the possibility of observing an episode of pair-wise Grangercausality intensification, particularly if the Spanish debt market is involved. The highest marginal effect of this value is found in the relationship that runs from Portugal to Spain (0.4769).

With regard to the role of private debt, we find empirical evidence supporting its importance in the cases of Ireland, Italy and Spain. Our results indicate that household's debt and non-financialcorporations' debt constitute relevant determinants in the transmission of the crisis from Italy and Spain, respectively (see Tables 10c and 10e); whilst banks' debt explains Granger-causality intensification from Ireland, Italy and Spain (see Tables 10b, 10c and 10e) ${ }^{29}$. The marginal effects of the variable that captures banks' debt are particularly high in the relationships running from Italy to Ireland (0.3227) and Spain (0.4019) and from the four relationships running from Ireland (they range from 0.5755 to 0.6256 ). The results obtained regarding the role played by private debt are

\footnotetext{
${ }^{28}$ Besides, its large debt market size may have benefited Italy twice since the TBTF theory might also hold in sovereigns' debt markets.

29 The finding of a significant role of bank's debt as determinant of Granger-causality intensification could be related to the transfer of risk from the banking sector to the public sector, since many governments were called on to support their banking system through direct capital injections and indirect balance-sheet support in the form of guarantees.
} 
very important in the Spanish and the Irish cases. In this respect, Table 7 shows that at the end of 2010, the ratio of non-financial corporations' debt-to-GDP was close to 90\% in Spain, whilst the ratio of banks' debt-to-GDP was $729.1 \%$ in Ireland. Therefore, as we claimed in the Introduction, the results support a central role of private debt, specifically, that hold by non-financial corporations and by the banking sector in the transmission of the crisis from Spain and Ireland, respectively. In both countries the origin of the debt crisis was mainly due to the private sector, being the domestic expansion financed by foreign borrowers.

As for the relevance of foreign bank's claims on public debt, it is noticeable that this variable is statistically significant in all the relationships that run from Ireland (Table 10b), whilst foreign bank's claims on the Irish banking debt is a key determinant in the relationship that runs from Greece to Ireland (Table 10a) and from Ireland to Portugal and Spain (Table 10b), although the associated the marginal effects are small.

Moreover, the instrument used to gauge the level of competitiveness (INF) is especially relevant when explaining the Granger-causality running from Greece (Table 10a) and Portugal (Table 10d), being particularly high the marginal effect associated with this variable in the relationship running from Greece to Italy (0.3349). On the other hand, the net position towards the rest of the world (CAC) is statistically significant with the expected negative sign in three out of the four relationships that run from Spain (Table 10e). Regarding the variable used to capture the country's growth potential (the unemployment rate, $\mathrm{U}$ ), we find that it shows a positive influence in the occurrence of an episode of causality intensification, which suggests that the weaker the economy, the higher the probability of sovereign debt crisis transmission. This conclusion is particularly relevant in the case of Greece, Italy, Portugal and Spain (see Tables 10a, 10c, 10d, and 10e). The highest marginal effects are obtained when this variable refers to the Spanish and the Italian unemployment rate: 0.7300 and 0.7347 in the relationships that run from Spain to Ireland and Italy, respectively; and 0.7757 in the relationship that runs from Italy to Spain. 
The results concerning the influence of investor sentiment indicate that the credit rating scale seems to be an important determinant in eleven out of the twenty cases considered. Besides, this variable presents an especially high marginal effect in some of the relationships where Italy is involved: from Italy to Greece (0.4372) and from Spain to Italy (0.3831).

To sum up, our results suggest that jointly with local risk factors, global risk factors are important determinants of the probability of occurrence of an episode of Granger-causality intensification in peripheral EMU public debt markets, especially in the relationships where Spain is involved. Regarding local risk factors, we found that not only variables that capture the evolution of macroeconomic imbalances but also those that gauge investors' sentiment are statistically significant. Specifically, our results support the idea that the euro area crisis faces several overlapping and reinforcing elements of fiscal (Greece and Portugal), banking (Ireland and Spain), and competitiveness (Southern periphery) crises, since variables that measure fiscal imbalances, private sector debt, or loss of competitiveness are particularly relevant in Greece and Portugal, Ireland and Spain, and Southern countries, respectively. Furthermore, we found that two variables are significant in all Granger-causal relationships examined: cross-border-banking linkages and the variable that depicts market liquidity. The relevance of the variable that captures financial linkages supports the idea that, in a context of high degree of integration of the banking system, transmission of the debt crisis through it has become a major issue to which it would be necessary to pay more attention. Besides, since we used the overall outstanding volume of debt in each country as a proxy of market liquidity, as expected, we obtained that liquidity premium decreases with the size of the market (benefiting large markets like the Italian one).

Finally, in Table 10 we also report the McFadden R-squared as a measure of goodness of the fit. As can be seen, it ranges from 0.6994 to 0.9115 , suggesting the relative success of the Probit regression models in predicting the values of the dependent variable within the sample ${ }^{30}$. As a further test to evaluate how well our estimated Probit models account for the observations, we compute the fitted

\footnotetext{
${ }^{30}$ The same conclusion is reached when performing the Pearson-type test of goodness-of-fit proposed by Hosmer and Lemeshow (2000).
} 
probability both within-sample and out-of-sample. It should be recalled that, when generating our indicator, we left out nine observations (April to December 2010) that were not used in the estimation. This allows us to evaluate the out-of-sample performance of the estimated Probit models based on the actual evolution of the instrumental variables. Figure 3 reports the results. Again, Figure 3a to Figure 3e report the results from the causal relationship running from Greece, Ireland, Italy, Portugal and Spain, respectively.

\author{
[Insert Figure 3 here]
}

As can be seen, the fitted probabilities closely track the evolution of the observed within-sample probabilities. Regarding the out-of-sample probabilities, our results suggest the occurrence of an additional episode of significant increase of Granger-causality in the last months of 2010 coinciding with a period of renewed turbulence in European debt markets (recall that the first rescue of Greece took place in May 2010 and that Ireland was rescued in November 2010).

\title{
4. Concluding remarks
}

In the current context of uncertainty in European sovereign debt markets, the analysis presented in this paper deals with a subject that has not been addressed deeply enough by the literature and is of particular relevance both to academics and to policy-makers.

In particular, this paper presents a dynamic approach to the analysis of the evolution of the degree of Granger-causality between peripheral EMU sovereign yields behavior (Greece, Ireland, Italy, Portugal and Spain). To this end, we have (1) tested for the existence of possible Granger-causal relationships between the evolution of these countries' ten-year yields, (2) examined the timevarying nature of these Granger-causal relationships to detect episodes of significant increase of causality between them, and (3) analyzed the determinants of these episodes. 
Since it seems increasingly clear that the origin of sovereign debt crisis in Europe has gone beyond the imbalances in public finances and that there is an obvious interconnection between public and private debt, we have analyzed the role of the latter in the episodes of Granger-causality intensification by using a unique dataset on private debt-to-GDP by sector (households, banks and non-financial corporations) in each peripheral EMU country. Besides, since the reasons that may explain transmission of sovereign debt crisis from one country to another can be fundamentalbased or investor behavior-based, we have included instruments that capture both types. In addition, we have borne in mind that fundamental-based interconnection works not only through real linkages, but also through financial linkages across countries. Specifically, in the current scenario of increased cross-border financial activity in the euro area, special attention has been paid to the impact of the degree of integration of the banking system on the speed at which a sovereign crisis in a country can spill over to others. This channel of transmission has generally been ignored by the recent literature, but its relevance is crucial.

The main findings of our analysis can be summarized as follows. Firstly, the results of the rolling analysis we apply in order to explore the dynamic causality between peripheral EMU yields suggest that there exist sub-periods of Granger-causality in all pair-wise relationships. Secondly, our empirical evidence suggests that the episodes with significant Granger-causality increase are concentrated around the first year of the launch of the EMU in 1999, the introduction of euro coins and banknotes in 2002 and, specially, the global financial crisis in the late-2000s. Therefore, our results indicate that the Granger-causality relationships between peripheral EMU yields have been significantly reinforced during the recent crises in sovereign debt markets since 2009. Thirdly, the results of the Probit models estimated to analyze the determinants of the previously detected episodes indicate that in all cases the variable that captures cross-border banking linkages is statistically significant. This finding suggests that, in a scenario of increased international financial activity in the euro area, transmission of the crisis in one country to other countries through the banking system may be a central issue (this is explained by the "financial trilemma" laid out by Schoenmaker, 2011). It is worth noting that macroeconomic imbalances in a specific country (the 
instruments we have used to capture them also indicate that they are key determinants of the probability of occurrence of an episode of Granger-causality's increase) lead to rising sovereign spreads and a devaluation of the government debt that is mirrored in banks' balance sheets. Moreover, regarding the role of private debt, we find evidence of its high relevance in the cases of Ireland and Spain. In these two countries, in contrast to Greece and Portugal (were the origin of the debt crisis was the structural public deficit), the private sector's indebtedness has been pointed out as the main cause of the debt crisis.

Therefore, as mentioned, our results suggest that euro area crisis faces multiple overlapping and mutually reinforcing elements of fiscal (Greece and Portugal), banking (Ireland and Spain), and competitiveness (Southern periphery) crises. This situation has lead many authors (see, for example, Bergsten and Kirkegaard, 2012) to state that the euro area is foremost facing a crisis of "institutional design". Indeed, the euro crisis began more than three years ago and there is still no end in sight. The main reason for this situation is that some of its root causes have been left largely unattended. In particular, no mechanism has been put in place to address the feedback loop between sovereigns and banks shown by our results. In this context, Pisani-Ferry (2012) lays out that the euro was imagined in the late 1980s in response to what was known as Mundell's trilemma, according to which no country can enjoy at the same time free capital flows, stable exchange rates and independent monetary policies. According to this author, twenty years later, the euro area faces another trilemma that stems from three of the basic principles upon which the European currency is based: the absence of co-responsibility over public debt, the strict no-monetary financing rule and the national character of banking systems. The coexistence of these three principles makes the euro area fragile. Therefore now, as twenty years ago, the question is which of the constraints the euro area should give in. The problem is that putting in place the necessary mechanism to solve the trilemma would involve transforming the euro area into a full-fledged monetary union with a fiscal and banking union. Although nothing short of a political union might ultimately be sufficient to ensure the long term viability of the monetary union, it is equally clear that it will take significant time to achieve even under the most optimistic assumptions. 
At this juncture, however, what appears more feasible and some of the short run policy implications that we suggest in this paper to fight this crisis are the following. The euro area would need (a) to take a decisive step forward by creating a banking union (see, for example, Pisani-Ferry et al., 2012, or Schoenmaker and Gros, 2012) and/or (b) to issue jointly guaranteed Eurobonds (see Favero and Missale, 2011, Delpla and von Weizsacker, 2010, 2011, or Claessens et al., 2012, among others).

\section{Acknowledgements}

We are very grateful to Javier Llordén from the Euro Area Accounts and Economic Data Division of the European Central Bank, for his valuable advice and help in the construction of the dataset on private debt-to-GDP by sector in each country and to Analistas Financieros Internacionales for kindly providing the credit rating dataset. The paper has substantially benefited from comments and suggestions from participants at the XXIV Symposium Moneda y Crédito in Madrid, the EC2 Conference in Florence, the 10th INFINITI Conference on International Finance in Dublin and the 21th European Financial Management Association in Barcelona. In particular, we would like to thank Petrod Migiakis (Bank of Greece), Gianni De Nicolò (International Monetary Fund) and Tatyana Sokolyk (Brock University). This paper is based upon work supported by the Government of Spain and FEDER under grant numbers ECO2010-21787-C03-01 and ECO2008-05565. Marta Gómez-Puig wants to thank the Instituto de Estudios Fiscales for financial support and Simón Sosvilla-Rivero thanks the Universitat de Barcelona and RFA-IREA for their hospitality. Responsibility for any remaining errors rests with the authors. 


\section{Appendix 1: Definition of the Explanatory Variables in the Probit models and Data Sources}

\begin{tabular}{|c|c|c|}
\hline NAME & VARIABLE & SOURCE \\
\hline CACXX & Current-account-balance-to-GDP of country XX & $\begin{array}{l}\text { OECD (monthly data are linearly interpolated from } \\
\text { quarterly observations) }\end{array}$ \\
\hline UXX & Unemployment rate of country XX & Eurostat (monthly data) \\
\hline INFXX & Inflation rate of country $\mathrm{XX}$ & $\begin{array}{l}\text { Eurostat (HICP monthly interannual rate of } \\
\text { growth) }\end{array}$ \\
\hline RATXX & Credit rating scale of country XX. & $\begin{array}{l}\text { Bloomberg: Standard \&Poor's, Moody's and Fitch } \\
\text { ratings for each government's debt. }\end{array}$ \\
\hline DEFXX & Government deficit-to-GDP of country XX. & $\begin{array}{l}\text { Eurostat (monthly data are linearly interpolated } \\
\text { from quarterly observations) }\end{array}$ \\
\hline XXLIQ & $\begin{array}{c}\text { Domestic Debt Securities. Public Sector } \\
\text { Amounts Outstanding (billions of US dollars) of } \\
\text { country XX. }\end{array}$ & $\begin{array}{l}\text { BIS Debt securities statistics. Table 18: Total debt } \\
\text { securities by residence of issuer -General } \\
\text { Government issues- (monthly data are linearly } \\
\text { interpolated from quarterly observations) }\end{array}$ \\
\hline XXGOVDEB & Government debt-to-GDP of country XX. & $\begin{array}{l}\text { Eurostat (monthly data are linearly interpolated } \\
\text { from quarterly observations) }\end{array}$ \\
\hline XXBANDEB & Banks' debt-to-GDP of country XX & $\begin{array}{l}\text { ECB's Monetary Financial Institutions balance } \\
\text { sheets and own estimates (monthly data). GDP has } \\
\text { been obtained from Eurostat (monthly data are } \\
\text { linearly interpolated from quarterly observations) }\end{array}$ \\
\hline XXNFIDEB & $\begin{array}{l}\text { Non-financial corporations' debt-to-GDP of } \\
\text { country XX }\end{array}$ & $\begin{array}{l}\text { ECB's Monetary Financial Institutions balance } \\
\text { sheets and own estimates (monthly data). GDP has } \\
\text { been obtained from Eurostat (monthly data are } \\
\text { linearly interpolated from quarterly observations) }\end{array}$ \\
\hline XXHOUDEB & Households' debt-to-GDP of country XX & $\begin{array}{l}\text { ECB's Monetary Financial Institutions balance } \\
\text { sheets and own estimates (monthly data). GDP has } \\
\text { been obtained from Eurostat (monthly data are } \\
\text { linearly interpolated from quarterly observations) }\end{array}$ \\
\hline XXBAN & $\begin{array}{l}\text { Foreign bank claims on banks debt-to-GDP of } \\
\text { country XX }\end{array}$ & $\begin{array}{l}\text { BIS Consolidated banking statistics. Table 9C: } \\
\text { Foreign claims by sector and type, ultimate risk } \\
\text { basis. GDP has been obtained from the OECD } \\
\text { (monthly data are linearly interpolated from } \\
\text { quarterly observations) }\end{array}$ \\
\hline XXPUB & $\begin{array}{l}\text { Foreign bank claims on government debt-to- } \\
\text { GDP of country XX }\end{array}$ & $\begin{array}{l}\text { BIS Consolidated banking statistics. Table 9C: } \\
\text { Foreign claims by sector and type, ultimate risk } \\
\text { basis. GDP has been obtained from the OECD } \\
\text { (monthly data are linearly interpolated from } \\
\text { quarterly observations) }\end{array}$ \\
\hline XXPRI & $\begin{array}{l}\text { Foreign bank claims on non-financial private } \\
\text { debt-to-GDP of country XX }\end{array}$ & $\begin{array}{l}\text { BIS Consolidated banking statistics. Table 9C: } \\
\text { Foreign claims by sector and type, ultimate risk } \\
\text { basis. GDP has been obtained from the OECD } \\
\text { (monthly data are linearly interpolated from } \\
\text { quarterly observations) }\end{array}$ \\
\hline XXYYBAN & $\begin{array}{l}\text { Percentage of the total foreign claims on country } \\
\text { XX held by country YY's banks }\end{array}$ & $\begin{array}{l}\text { BIS Consolidated banking statistics. Table 9D: } \\
\text { Foreign claims by nationality of reporting banks, } \\
\text { ultimate risk basis and own estimates. }\end{array}$ \\
\hline RISK & $\begin{array}{c}\text { Chicago Board Options Exchange Market } \\
\text { Volatility Index (VIX) }\end{array}$ & Chicago Board Options Exchange \\
\hline
\end{tabular}




\section{References}

Abad, P., Chuliá, H., Gómez-Puig, M., 2010. EMU and European government bond market integration. Journal of Banking and Finance 34, 2851-2860.

Abad, P., Chuliá, H., Gómez-Puig, M., 2012. Time-varying integration in European government bond markets. European Financial Management, forthcoming

Andenmatten, S., Brill, G., 2011. Measuring co-movements of CDS premia during the Greek debt crisis. Discussion Papers 11-04, Department of Economics, University of Bern.

Allen, F.; Beck; T., Carletti; E., Lane; P. L., Schoenmaker, D., Wagner, W., 2011. Cross-Border Banking in Europe: Implications for Financial Stability and Macroeconomic Policies. Centre for Economic Policy Research Editions, London.

Akaike, H., 1974. A new look at the statistical model identification. IEEE Transactions on Automatic Control 19, 716-723

Banerjee, A., Dolado, J., Galbraith, J., Hendry, D., 1993. Cointegration, Error Correction and the Econometric Analysis of Nonstationary Series. Oxford University Press, Oxford.

Bank for International Settlements, 2011. International banking and financial market developments, BIS Quarterly Review, June.

Barnes, S., Lane, P. R., Radziwill,. A., 2010. Minimising risks from imbalances in European banking. Working Paper 828, Economics Department, Organization for Economomic Cooperation and Development.

Barrios, S.; Iversen; P., Lewandowska M., Setze, R., 2009. Determinants of intra-euro area government bond spreads during the financial crisis. Economic Paper 388, European Commission.

Bayoumi, T., Goldstein, M., Woglom, G., 1995. Do credit markets discipline sovereign borrowers? Evidence from the US States. Journal of Money, Credit and Banking 27, 1046-1059.

Bekaert, G.; Ehrmann; M., Fratzscher, M., Mehl, A., 2011. Global crises and equity market contagion. Discussion Paper 8438, Centre for Economic Policy Research.

Bekaert, G., Hoerova, M., Lo Duca, M. (2012). Risk, uncertainty and monetary policy. Working Paper No 229, National Bank of Belgium.

Bergsten, F. C., Kirkegaard, J. F., 2012. The coming resolution of the European crisis: An update. Policy Brief 12-18, Peterson Institute for International Economics.

Bernoth, K.; Erdogan, B., 2012. Sovereign bond yield spreads: A time-varying coefficient approach, Journal of International Money and Finance 31, 975-995.

Blanco, R., 2001. The Euro-area government securities markets. Recent developments and implications for market functioning. Working Paper 0120, Banco de España.

Bloom, N, (2009). The impact of uncertainty shocks. Econometrica, 77, 623-685.

Bolton, P., Jeanne, O., 2011. Sovereign default risk and bank fragility in financially integrated economies. Discussion Paper 8368, Centre for Economic Policy Research.

Broner, F., Ventura, J., 2011. Globalization and risk sharing. Review of Economic Studies 78, 4982.

Carrión-i-Silvestre, J. L., Sansó-i-Roselló, A., Ortuño, M. A., 2001. Unit root and stationarity tests wedding. Economics Letters 70, 1-8.

Claessens, S., Mody, A., Vallée, S., 2012. Paths to Eurobonds. Working Paper. 12/172, International Monetary Fund.

Codogno, L., Favero, C., Missale, A., 2003. Yield spreads on EMU government bonds. Economic Policy 18, 503-532. 
Delpla, J, von Weizsäcker, J., 2010. The blue bond proposal. Policy Brief 2010/03, Bruegel.

Delpla, J, von Weizsäcker, J., 2011. Eurobons: The blue bond concept and its implications, Policy Contribution 2011/02, Bruegel.

Dolado, J. J., Jenkinson, T., Sosvilla-Rivero, S., 1990. Cointegration and unit roots. Journal of Economic Surveys 4,149-173.

Dornbusch, R., Park, Y. C., Claessens, S., 2000. Contagion: Understanding how it spreads. The World Bank Research Observer 15, 177-198.

Ejsing, J., Lemke, W., 2009. The Janus-headed salvation: sovereign and bank credit risk premia during 2008-09. Working Paper 1127, European Central Bank.

Elliott, G., Thomas J. R., Stock, J. H., 1996. Efficient tests for an autoregressive unit root. Econometrica 64, 813-836.

Economides, N., Siow, A., 1988. The division of markets is limited by the extent of liquidity (spatial competition with externalities). American Economic Review 78 (1), 1719-734.

Favero, C., Missale A., 2011. Sovereign spreads in the euro area. Which prospects for a Eurobond? Discussion Paper 8637. Center for Economic Policy Research.

Favero, C.A., Pagano, M., von Thadden, E. L., 2010. How does liquidity affect government bond yields? Journal of Financial and Quantitative Analysis 45: 107-134.

Forbes, K., Rigobon, R., 2002. No contagion, only interdependence: Measuring stock market comovements. Journal of Finance 57, 2223-2261.

Gennaioli, N., Martin, A. Rossi, S., 2010. Sovereign default, domestic banks and financial institutions. Economics Working Paper 1170, Department of Economics and Business, Universitat Pompeu Fabra

Gerlach, S., Schulz, A., Wolff, G. B., 2010. Banking and sovereign risk in the euro area. Discussion paper series 1: Economic studies, Deutsche Bundesbank, Research Centre.

Gómez-Puig, M., 2006. Size matters for liquidity: Evidence from EMU sovereign yield spreads. Economics Letters 90, 156-162.

Gómez-Puig, M., 2008. Monetary integration and the cost of borrowing. Journal of International Money and Finance 27, 455-479.

Gómez-Puig M., 2009a. The immediate effect of Monetary Union over UE-15's sovereign debt yield spreads. Applied Economics 41, 929-939.

Gómez-Puig, M., 2009b. Systemic and idiosyncratic risk in UE-15 sovereign yield spreads after seven years of Monetary Union. European Financial Management 15, 971-1000.

Granger, C. W. J., 1969. Investigating causal relations by econometric models and cross-spectral methods. Econometrica 37, 24-36.

Grabowsky, W., 2007. Integrated time series in binary choice models. In Welfe, A., Welfe, W. (Eds.) 33rd International Conference MACROMODELS'06, IEEE, New York.

Gray, D. F., 2009. Modeling financial crises and sovereign risks. Annual Review of Financial Economics 1, 117-144.

Gros, D., 2011. External versus domestic debt in the euro crisis. Policy Brief 243, Centre for European Policy Studies.

Gros, D., Mayer, T., 2011. Debt reduction without default? Policy Brief 233, Centre for European Policy Studies.

Goodhart, C.A.E., Huang, H., 2005. The lender of last resort. Journal of Banking \& Finance 29, 1059-1082. 
Hendry, D.F., 1995. Dynamic Econometrics. Oxford University Press, Oxford.

Hendry, D. F., Mizon, G. E., 1999. The pervasiveness of Granger causality in Econometrics. In Engle, R. F., White, H. (Eds.) Cointegration, Causality, and Forecasting. A Festsschrift in Honour of Clive W. J. Granger, Oxford University Press, Oxford.

Hoover, K. D., 2001. Causality in Macroeconomics. Cambridge University Press, Cambridge.

Hosmer, D.W., Lemeshow, S., 2000. Applied Logistic Regression. John Wiley and Sons, New York.

Hsiao, C., 1981. Autoregressive modelling and money-income causality detection. Journal of Monetary Economics 7, 85-106.

International Monetary Fund, 2010. Global Financial Stability Report, April, International Monetary Fund, Washington, D. C.

Johansen, S., 1991. Estimation and hypothesis testing of cointegration vectors in Gaussian vector autoregressive models. Econometrica 59, 1551-1580.

Johansen, S., 1994. The role of the constant and linear terms in cointegration analysis of nonstationary variables. Econometric Reviews 13, 205-229.

Johansen, S., 1995. Likelihood-based Inference in Cointegrated Vector Autoregressive Models. Oxford University Press, Oxford.

Kalemi-Ozcan, S.; Papaioannou, E., Peydró-Alcalde, J. L. 2010. What lies beneath the Euro's effect on financial integration? Currency risk, legal harmonization, or trade? Journal of International Economics 81, 75-88.

Korajczyk, R., Sadka, R., 2008. Pricing the commonality across alternative measures of liquidity. Journal of Financial Economics 87 (1), 45-72.

Lane, P. R.., 2011. The Irish crisis. Discussion Paper 8287, Centre for Economic Policy Research.

MacKinnon, J. G., Haug, A. A., Michelis, L., 1999: Numerical distribution functions of likelihood ratio tests for cointegration. Journal of Applied Econometrics 14, 563-577.

McCauley, R., Remolona, E., 2000. Size and liquidity of government bond markets. BIS Quarterly Review.

Mody, A., 2009. From bear sterns to Anglo Irish: How Eurozone sovereign spreads related to financial sector vulnerability. Working Paper 09/108, International Monetary Fund.

Ng, S., Perron, P., 2001. Lag length selection and the construction of unit root tests with good size and power. Econometrica 69, 1519-1554.

Nielsen, B., Rahbek, A., 2000. Similarity issues in cointegration analysis. Oxford Bulletin of Economics and Statistics 62, 5-22.

Park, J. Y., Phillips, P. C. B., 2000. Nonstationary binary choice, Econometrica 68, 1249-1280.

Pastor, L., Stambaugh. R. F. 2003, Liquidity risk and expected stock returns. Journal of Political Economy 111, 642-685.

Phillips, P. C. B., Perron, P., 1988. Testing for a unit root in times series regression. Biometrika 75, 335-346.

Pisani-Ferry, J., 2012. The euro crisis and the new impossible trinity. Policy Contribution 2012/01, Bruegel.

Pisani-Ferry, J., Sapir, A., Veron, N., Wolff, G. B., 2012. What kind of European Banking Union? Policy Contribution 2012/01, Bruegel.

Schoenmaker, D., 2011. The financial trilemma. Economics Letters 111, 57-59.

Schoenmaker, D., Gros, D., 2012. A European deposit insurance and resolution fund. Working Document 364, Centre for European Policy Studies. 
Sgherri, S., Zoli, E., 2009. Euro area sovereign risk during the crisis. IMF Working Papers 09/222, International Monetary Fund.

Sims, C. A., 1972. Money, income, and causality. American Economic Review. 62, 540-552.

Spiegel, M., 2009a. Monetary and financial integration in the EMU: Push or pull? Review of International Economics 17, 751-776.

Spiegel, M., 2009b. Monetary and financial integration: Evidence from the EMU. Journal of the Japanese and International Economies 23, 114-130.

Thornton, D. L., Batten, D. S., 1985. Lag-length selection and tests of Granger causality between money and income. Journal of Money, Credit, and Banking 27, 164-178.

Williams, E. J., 1959. Regression analysis. Wiley, New York. 
Figure 1a. Daily 10-year sovereign yields in peripheral EMU countries: 1999-2010

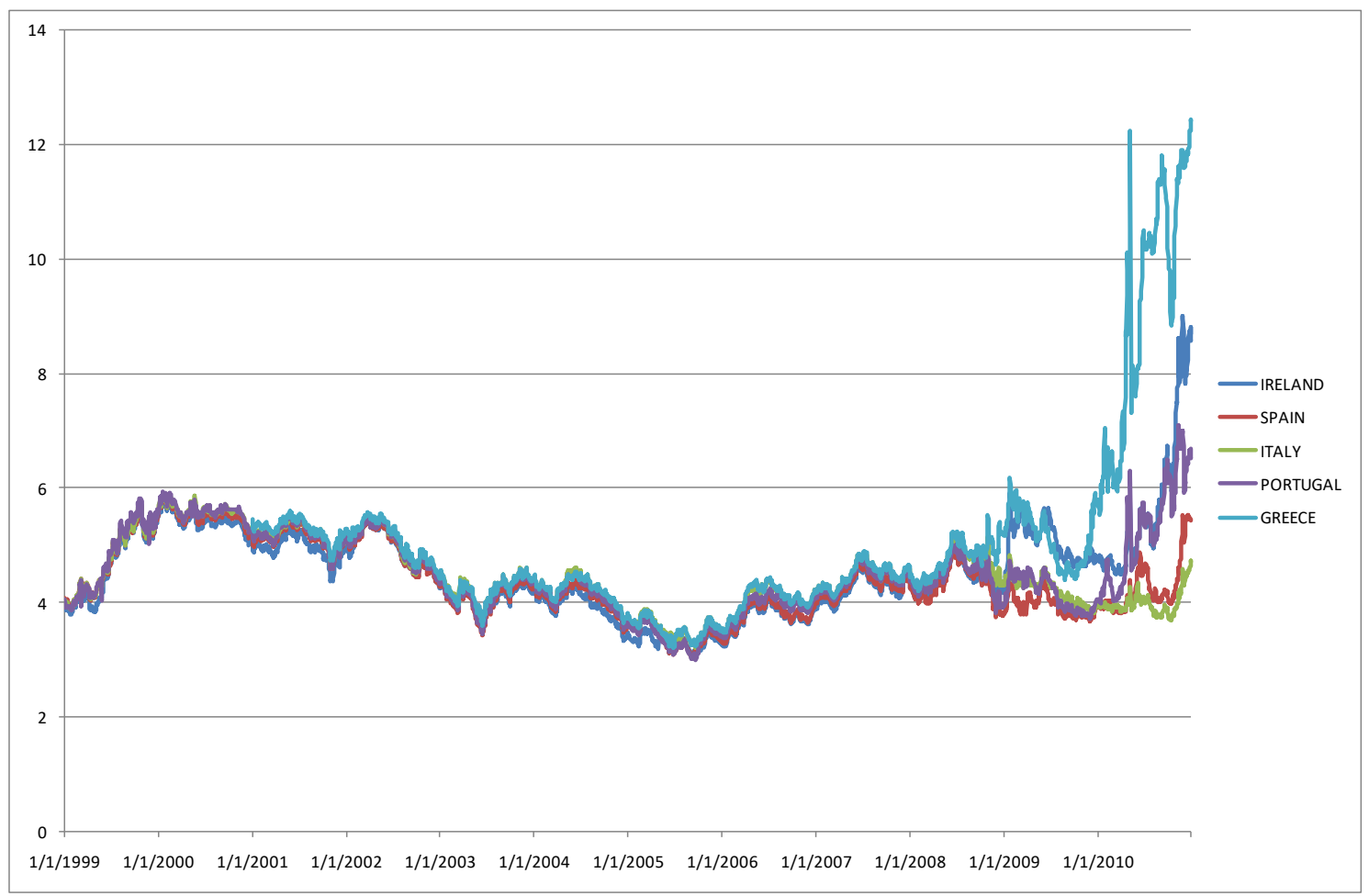

Figure 1b. Daily 10-year sovereign yield spreads over Germany: 1999-2010

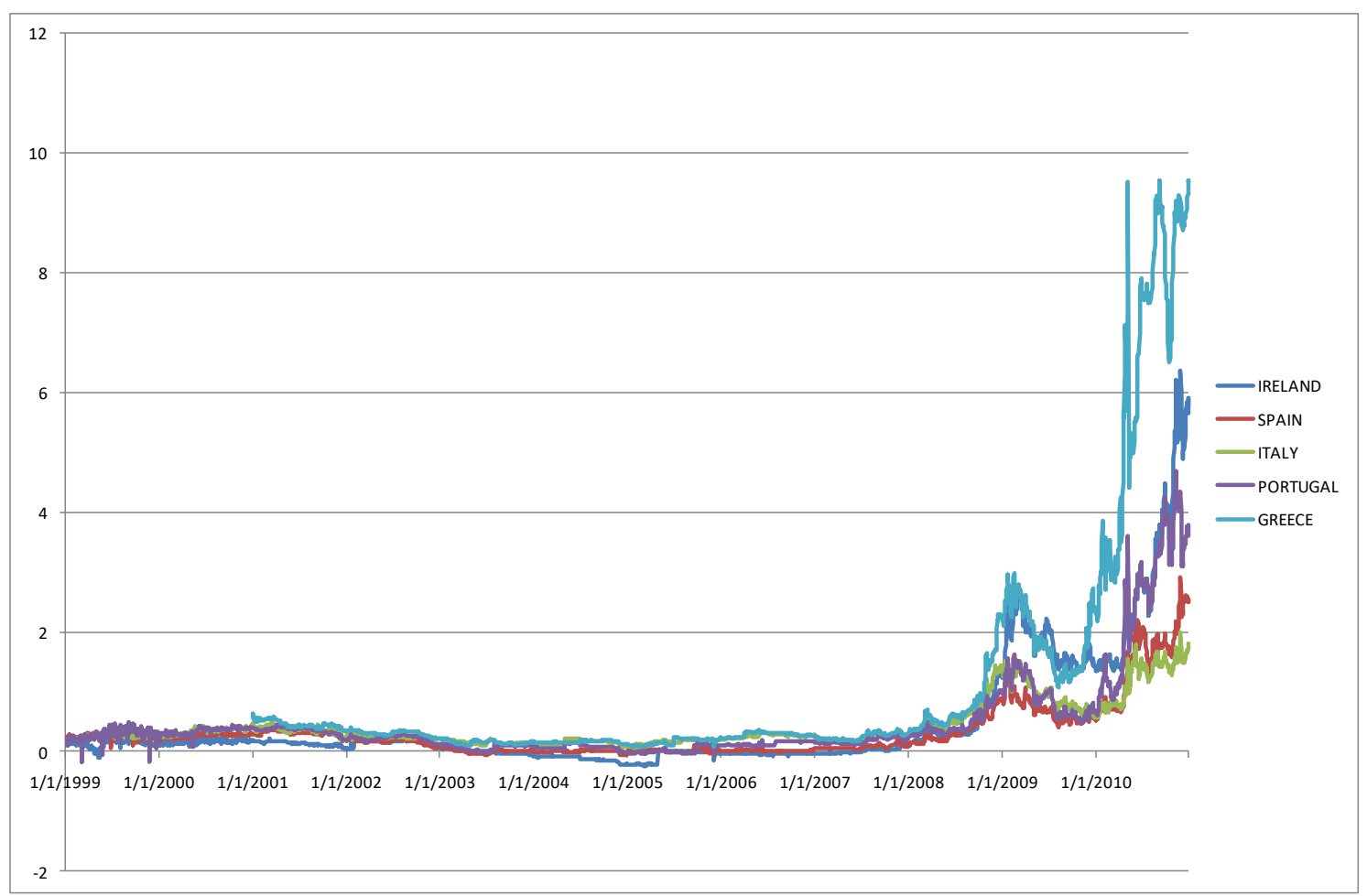


Figure 2a: FPE sequence from rolling regressions running from Greece

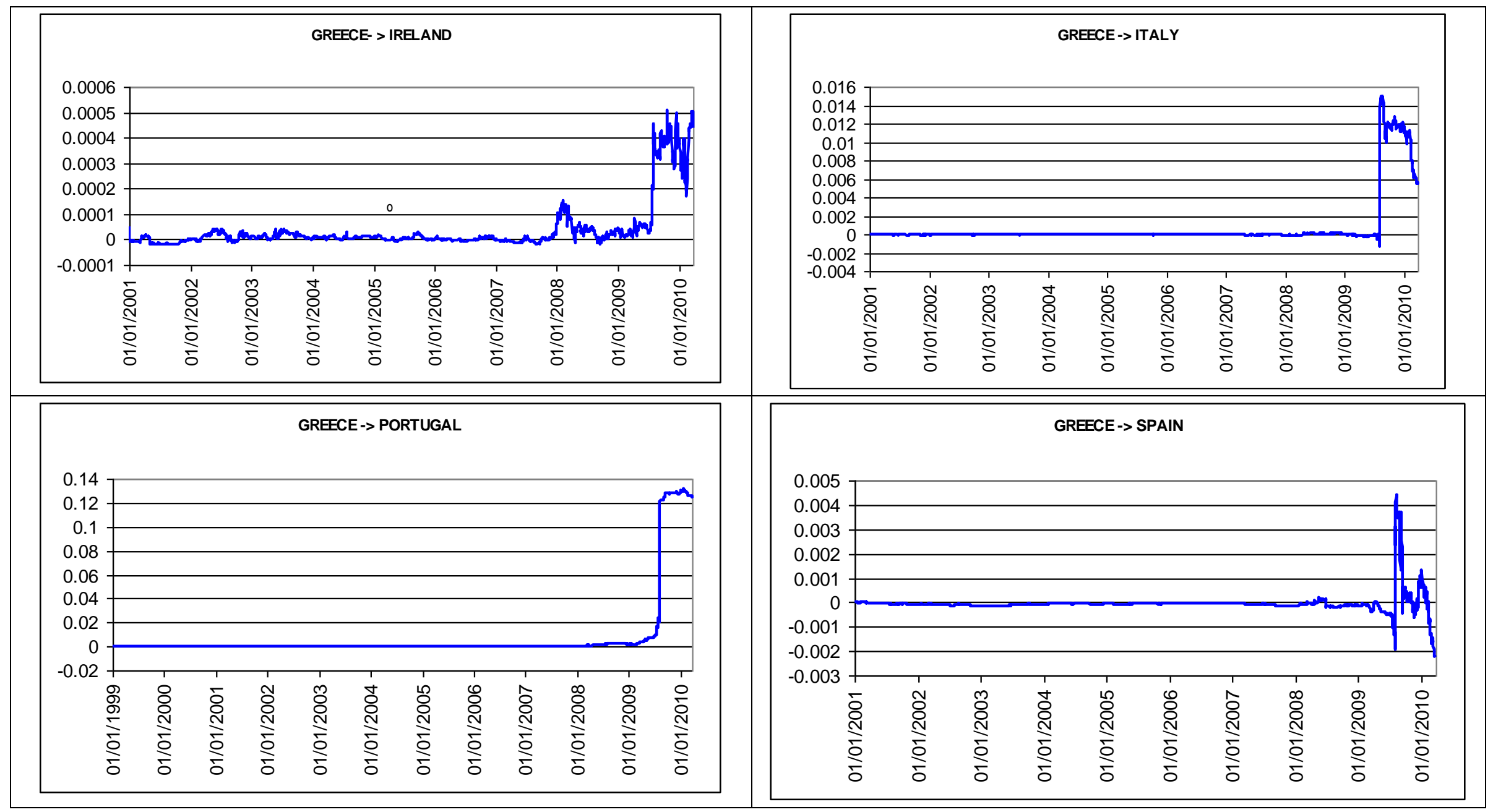


Figure 2b: FPE sequence from rolling regressions running from Ireland

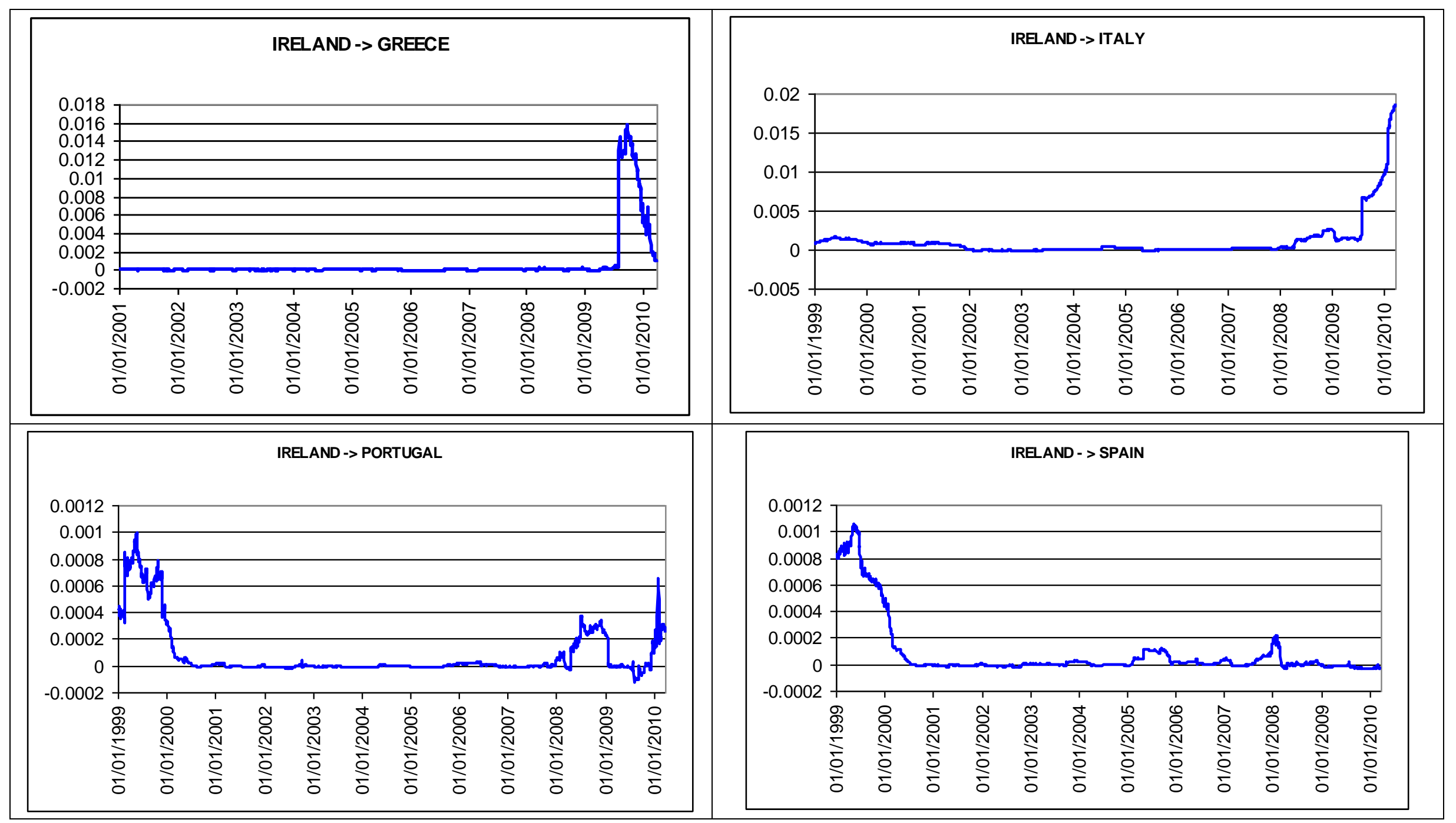


Figure 2c: FPE sequence from rolling regressions running from Italy

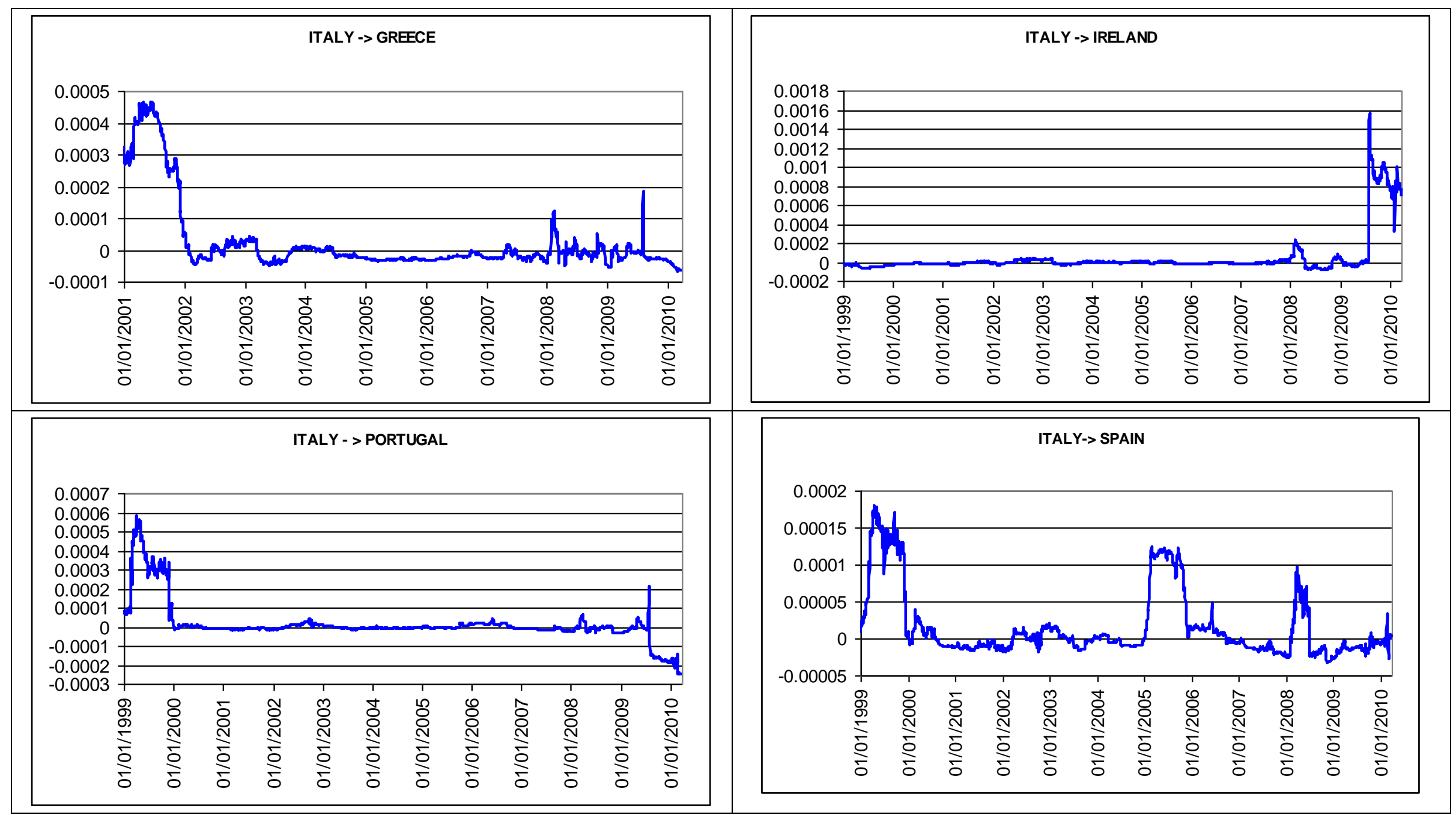


Figure 2d: FPE sequence from rolling regressions running from Portugal

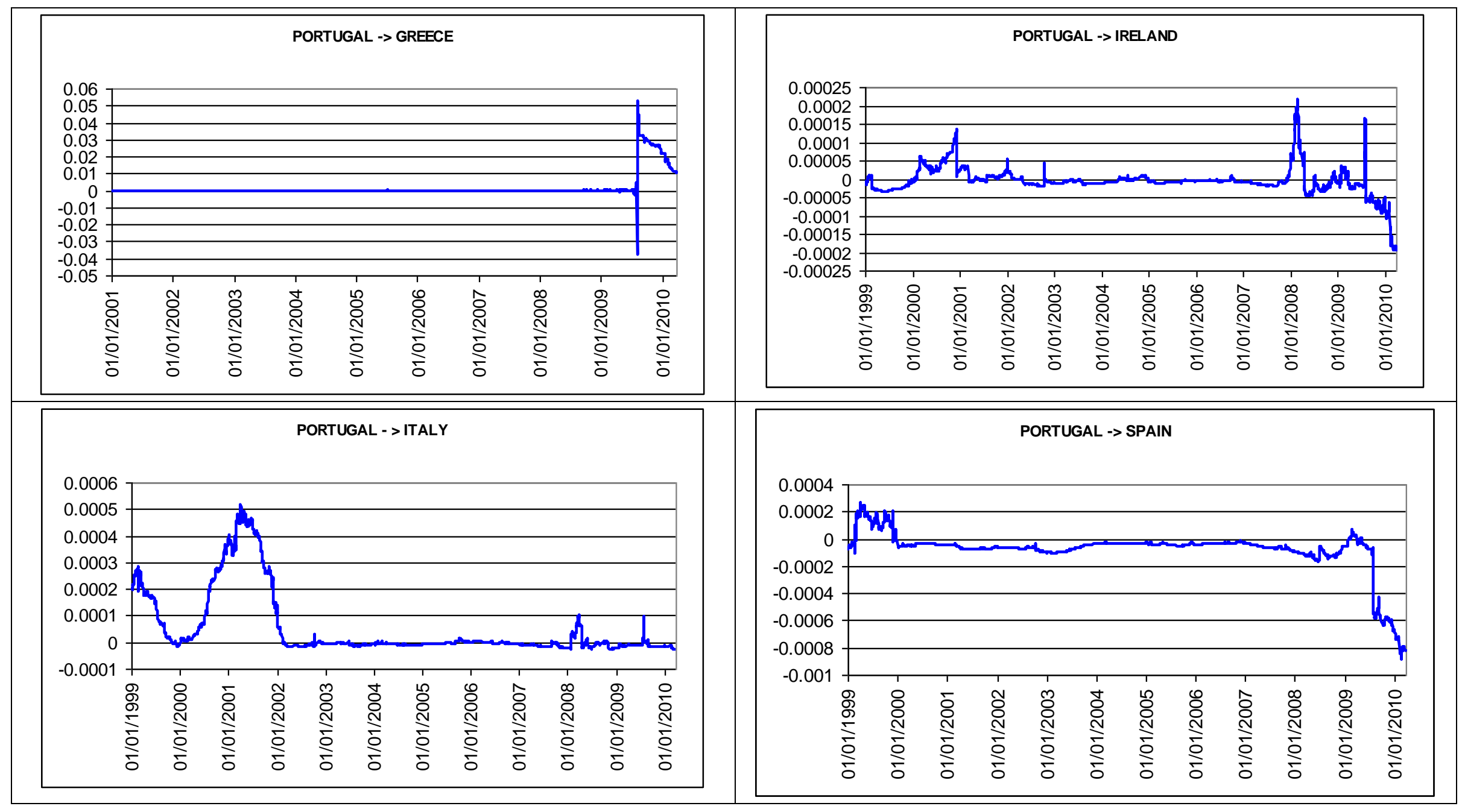


Figure 2e: FPE sequence from rolling regressions running from Spain
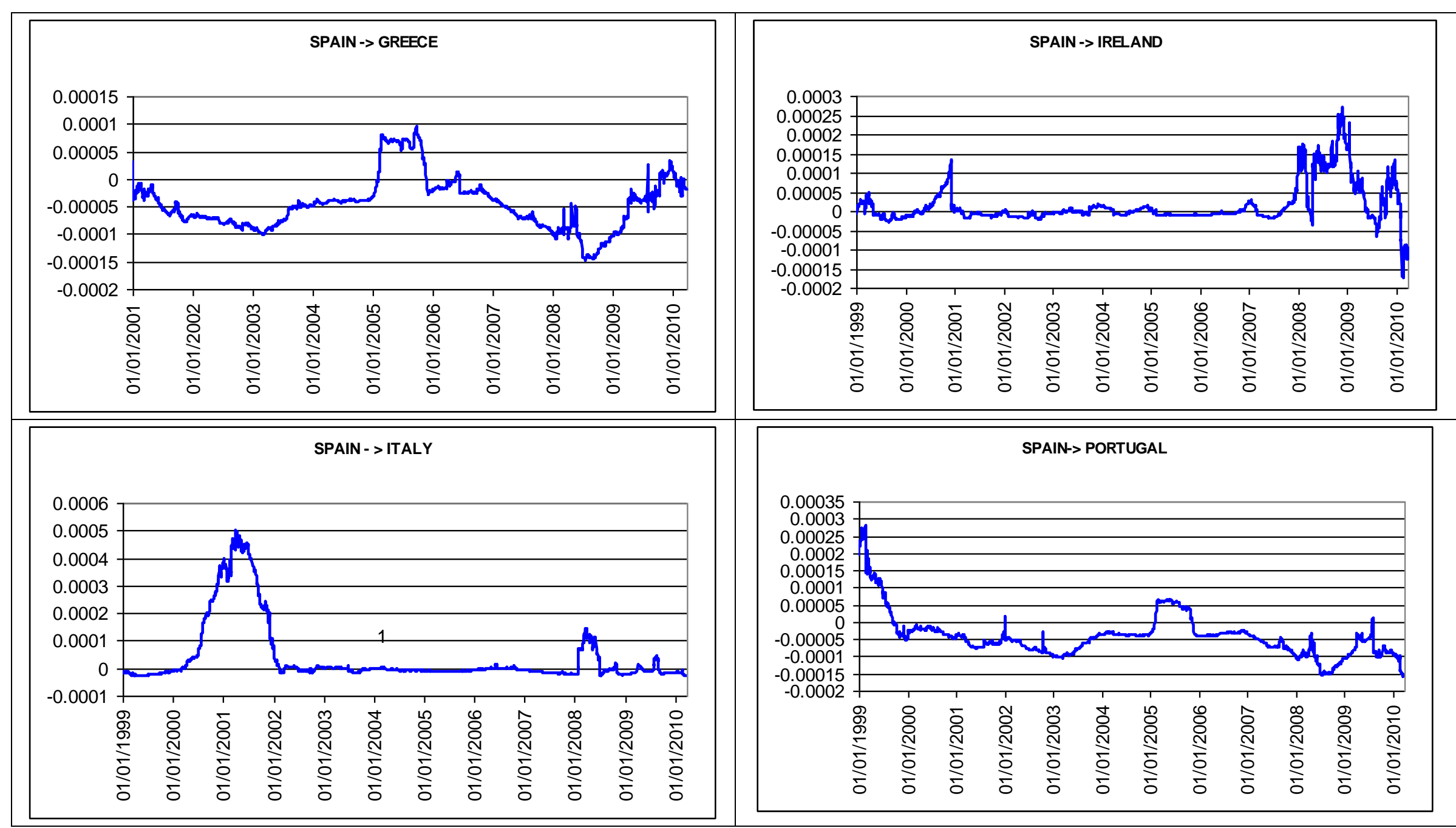
Figure 3a: Probit results, causal relationships running from Greece

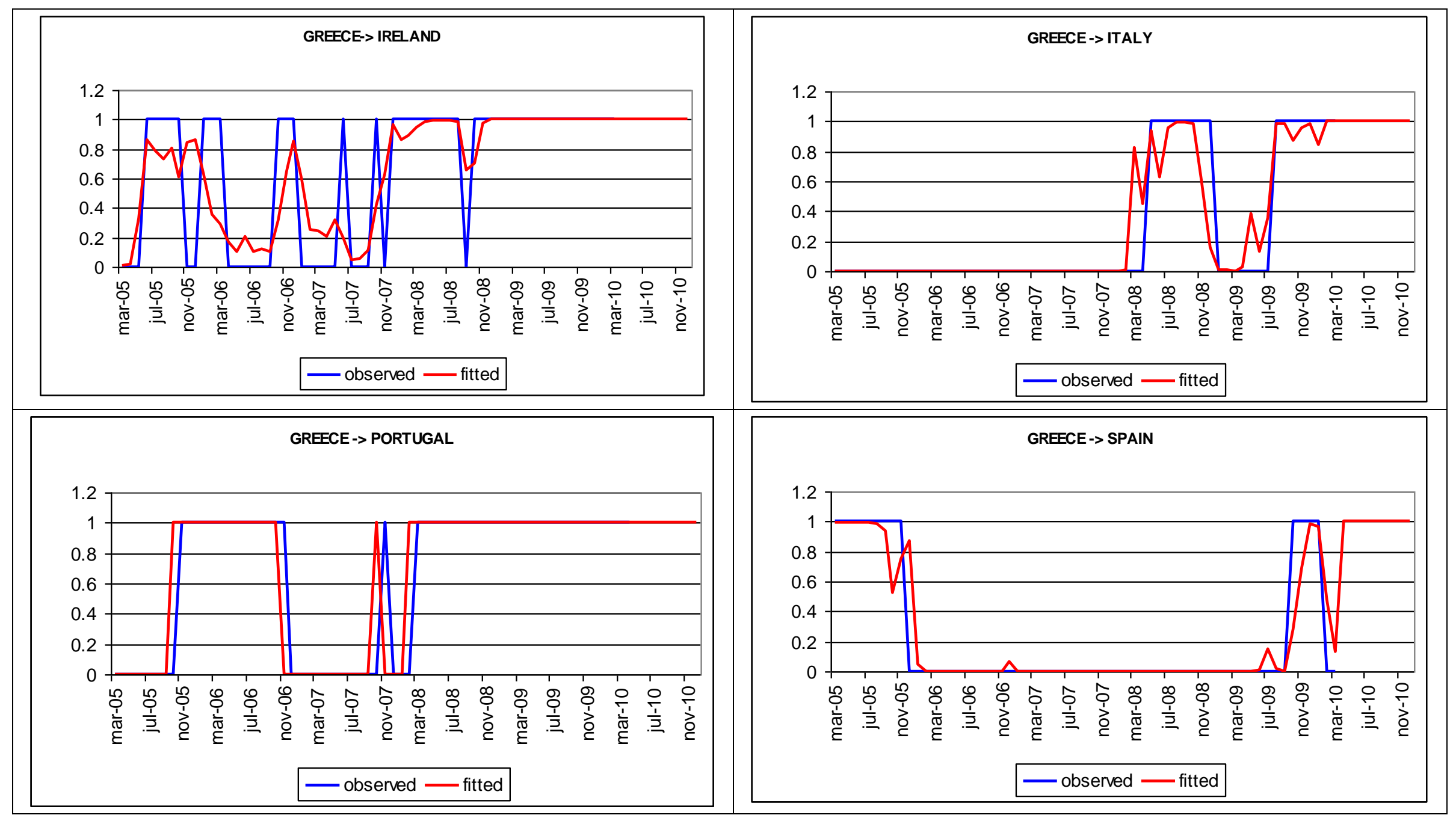




\section{Figure 3b: Probit results, causal relationships running from Ireland}

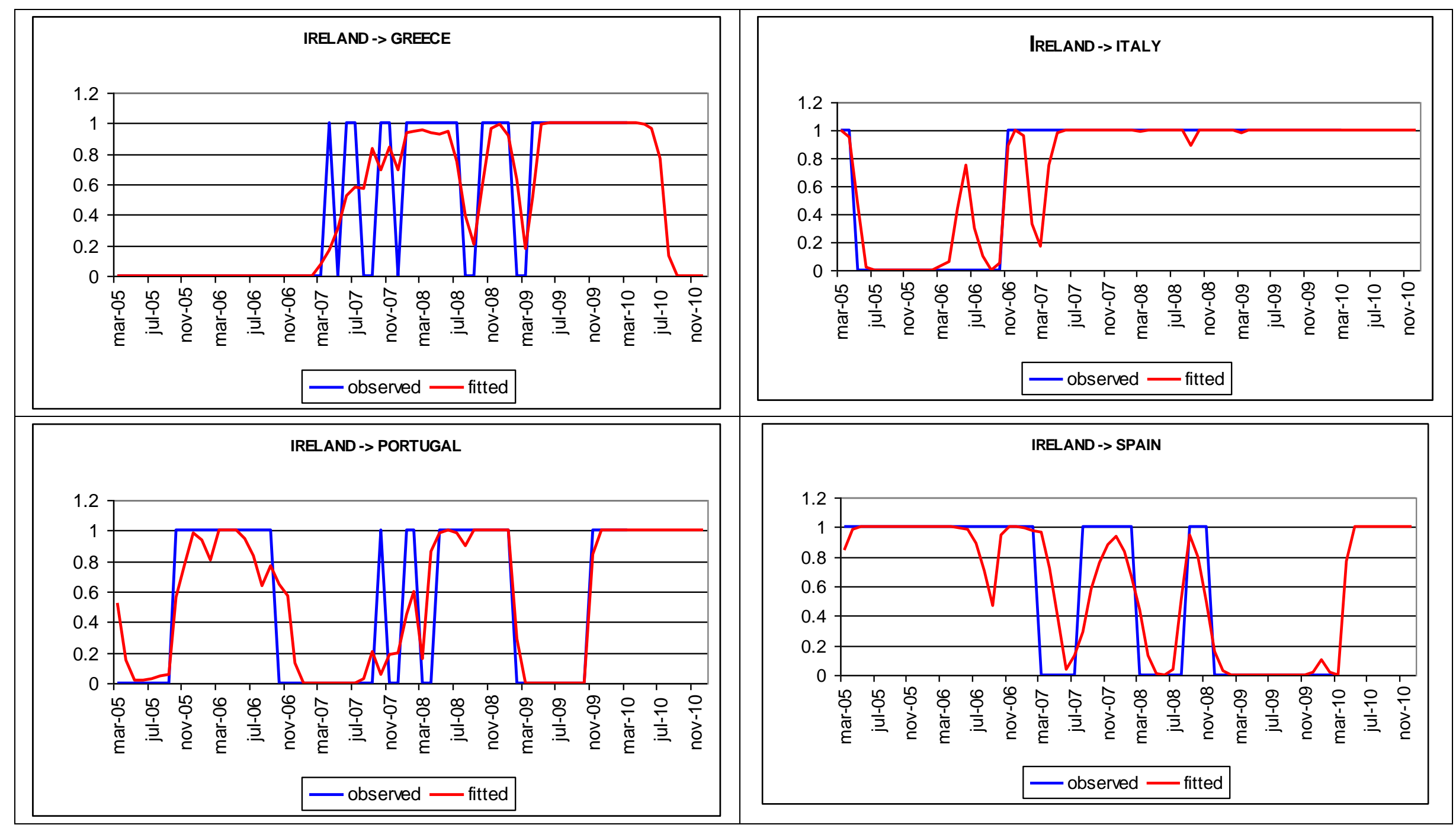


Figure 3c: Probit results, causal relationships running from Italy

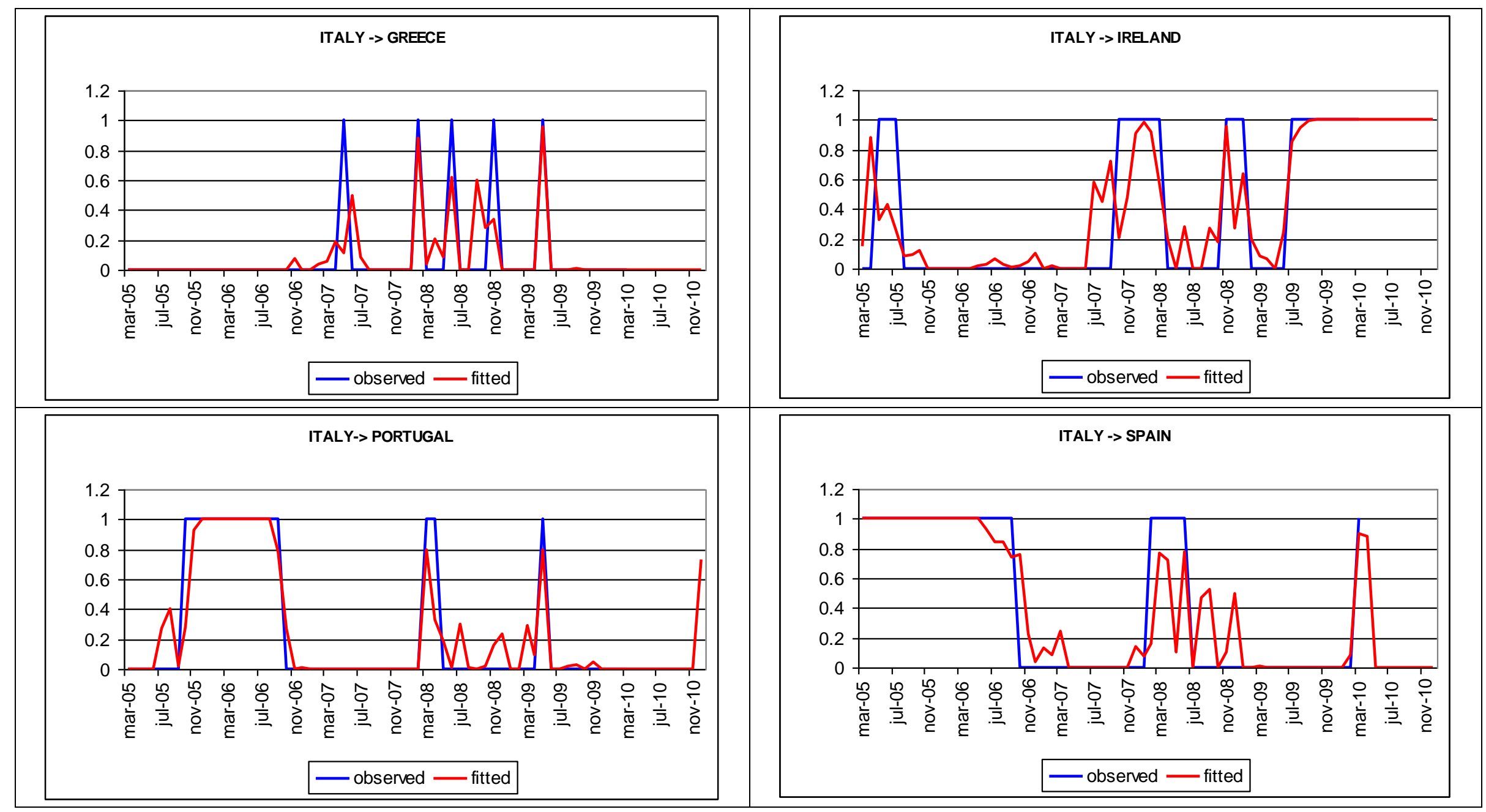


Figure 3d: Probit results, causal relationships running from Portugal

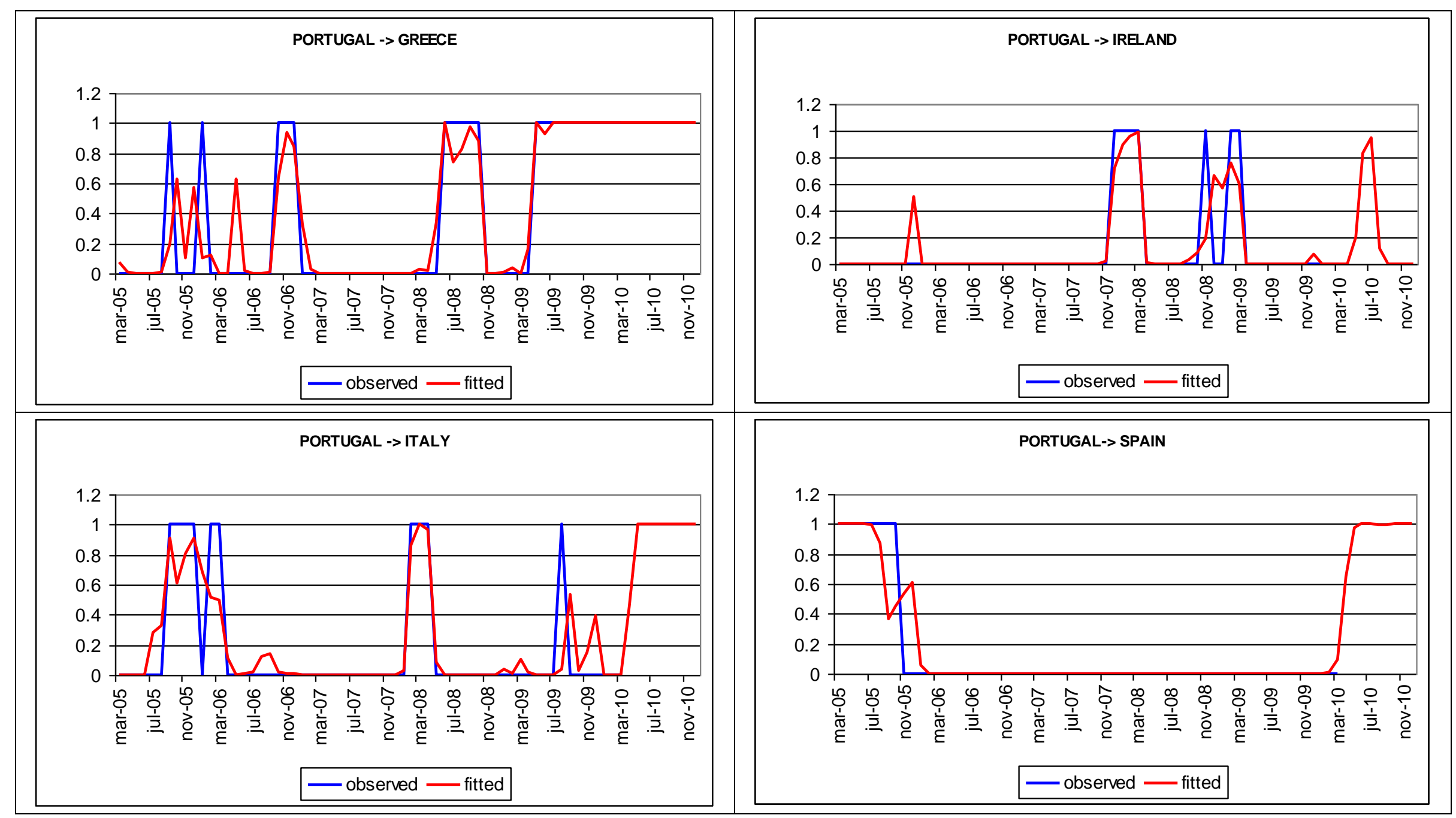


Figure 3e: Probit results, causal relationships running from Spain

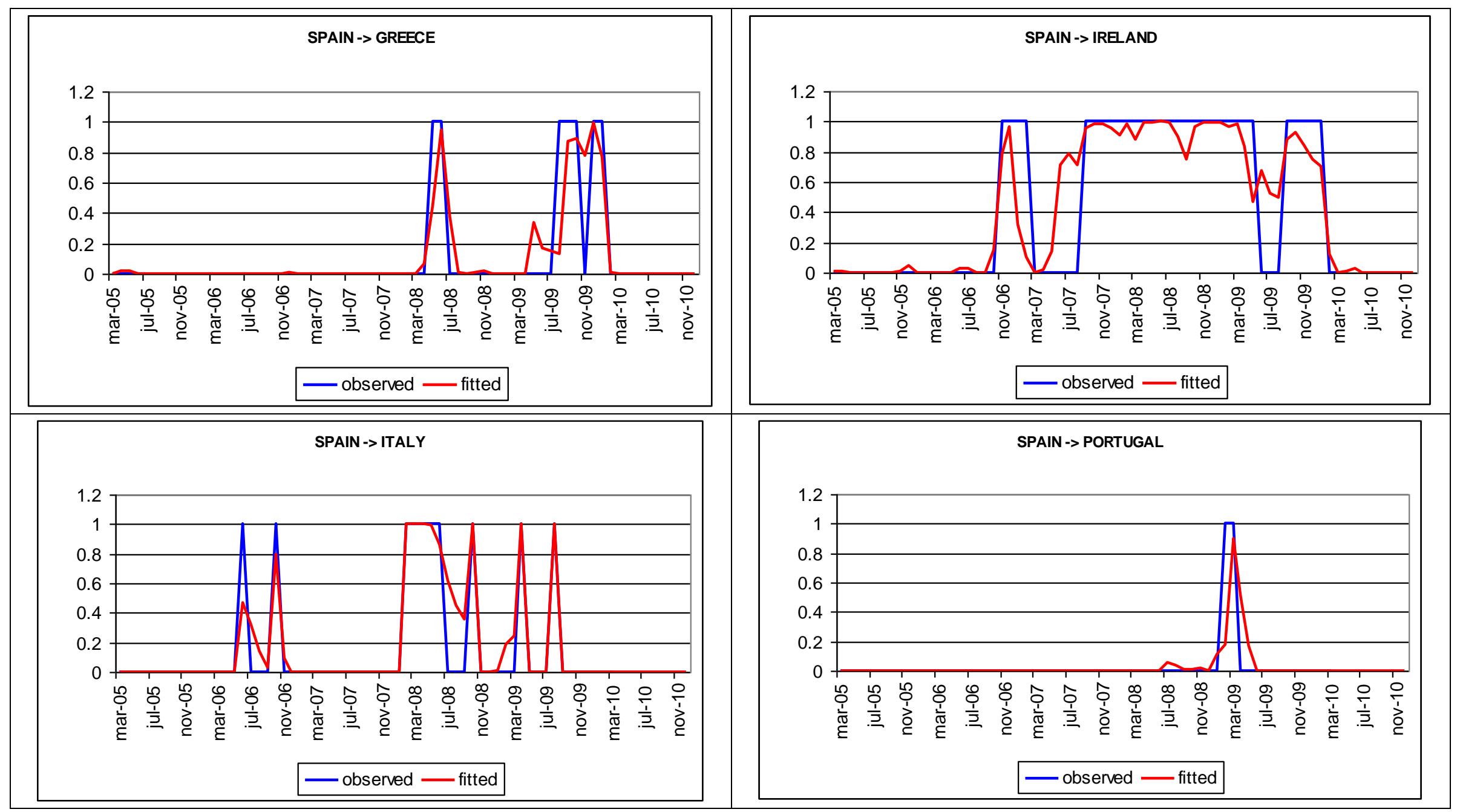


Table 1. Descriptive statistics

\begin{tabular}{|c|c|c|c|c|c|}
\hline & GR & IE & IT & PT & SP \\
\hline Mean & 4.995 & 4.543 & 4.491 & 4.541 & 4.379 \\
\hline Median & 4.544 & 4.459 & 4.374 & 4.405 & 4.232 \\
\hline Maximum & 12.440 & 9.012 & 5.879 & 7.104 & 5.870 \\
\hline Minimum & 3.206 & 3.038 & 3.215 & 2.997 & 3.025 \\
\hline Std. Dev. & 1.637 & 0.828 & 0.615 & 0.722 & 0.650 \\
\hline Skewness & 2.714 & 1.236 & 0.343 & 0.423 & 0.376 \\
\hline Kurtosis & 10.589 & 7.304 & 2.268 & 2.793 & 2.230 \\
\hline Jarque-Bera & 9468.5 & 3213.9 & 131.5 & 99.0 & 151.2 \\
\hline Observations & 2610 & 3131 & 3131 & 3131 & 3131 \\
\hline \multicolumn{6}{|c|}{ Panel B: First differences } \\
\hline & DGR & DIE & DIT & DPT & DSP \\
\hline Mean & 0.003 & 0.002 & 0.000 & 0.001 & 0.000 \\
\hline Median & 0.000 & 0.000 & 0.000 & 0.000 & 0.000 \\
\hline Maximum & 1.304 & 0.682 & 0.213 & 0.546 & 0.253 \\
\hline Minimum & -4.323 & -1.028 & -0.319 & -1.470 & -0.441 \\
\hline Std. Dev. & 0.117 & 0.058 & 0.041 & 0.062 & 0.044 \\
\hline Skewness & -17.879 & -1.162 & 0.181 & -4.230 & -0.077 \\
\hline Kurtosis & 720.496 & 48.784 & 5.562 & 113.490 & 7.960 \\
\hline Jarque-Bera & 56102048.0 & 274076.8 & 873.0 & 1601451.0 & 3211.0 \\
\hline Observations & 2609 & 3130 & 3130 & 3130 & 3130 \\
\hline
\end{tabular}

Note: GR, IE, IT, PT and SP stand for Greece, Ireland, Italy, Portugal and Spain respectively. 
Table 2. Augmented Dickey- Fuller tests for unit roots.

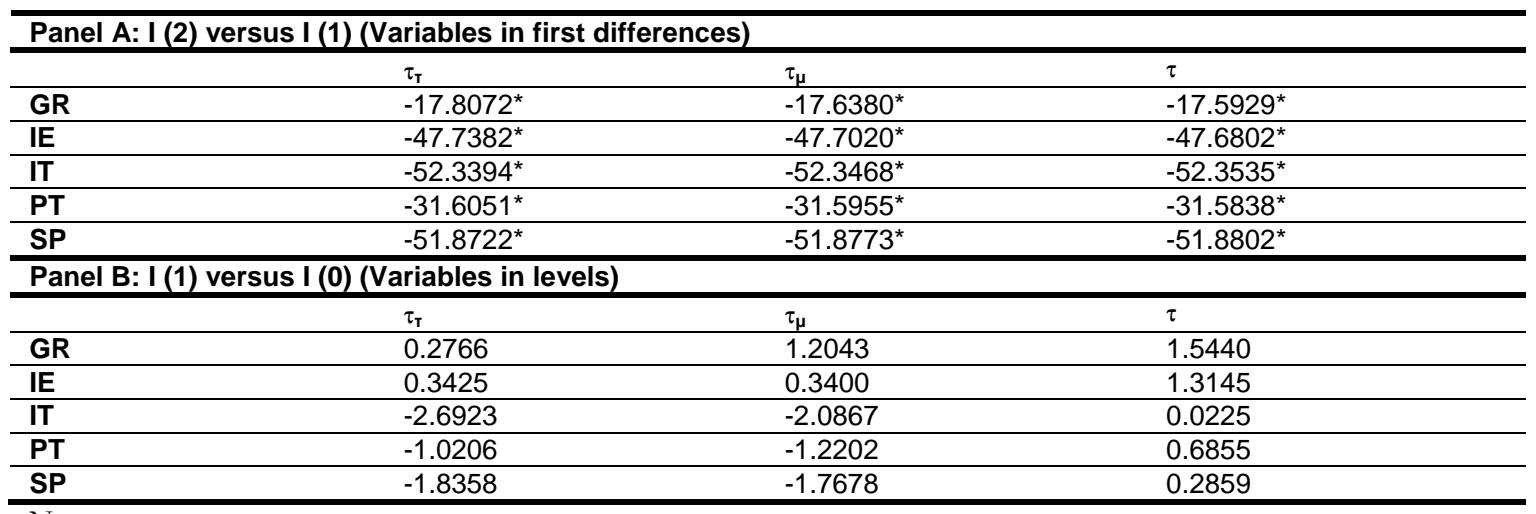

Notes:

The ADF statistic is a test for the null hypothesis of a unit root.

$\tau_{\tau}, \tau_{\mu}$ and $\tau$ denote the ADF statistics with drift and trend, with drift, and without drift, respectively.

* denotes significance at the $1 \%$ level. Critical values based on MacKinnon (1996)

GR, IE, IT, PT and SP stand for Greece, Ireland, Italy, Portugal and Spain respectively.

Table 3. KPSS tests for stationarity

\begin{tabular}{lll}
\hline Panel A: I (2) versus I (1) (Variables in first differences) & $\tau_{\boldsymbol{\mu}}$ & 0.2574 \\
\hline GR & 0.1052 & 0.3287 \\
\hline IE & 0.0877 & 0.1072 \\
\hline IT & 0.1083 & 0.1868 \\
\hline PT & 0.1103 & 0.1551 \\
\hline SP & 0.0975 & $\tau_{\mu}$ \\
\hline Panel B: I (1) versus I (0) (Variables in levels) & $1.8948^{*}$ \\
\hline & $\tau_{\boldsymbol{T}}$ & $1.1528^{*}$ \\
\hline GR & $0.9832^{*}$ & $2.9237^{*}$ \\
\hline IE & $1.1606^{*}$ & $1.6140^{*}$ \\
\hline IT & $0.6825^{*}$ & $3.0079^{*}$
\end{tabular}

Notes:

The KPSS statistic is a test for the null hypothesis of stationarity.

$\tau_{\tau}$ and $\tau_{\mu}$ denote the KPSS statistics with drift and trend, and with drift, respectively.

* denotes significance at the $1 \%$ level. Asymptotic critical values based on Kwiatkowski et al. (1992. Table 1)

GR, IE, IT, PT and SP stand for Greece, Ireland, Italy, Portugal and Spain respectively. 
Table 4. Cointegration tests

\begin{tabular}{|c|c|c|c|}
\hline & $\begin{array}{c}\text { Hypothesized numbers of } \\
\text { cointegrating relations }\end{array}$ & Trace statistic & p-value $^{\mathbf{b}}$ \\
\hline \multirow{2}{*}{ GR. IE } & None & $20.3839^{* *}$ & 0.0481 \\
& At most one & 1.0135 & 0.9498 \\
\hline GR. IT & None & 16.5832 & 0.1488 \\
& At most one & 3.0084 & 0.5791 \\
\hline GR. PT & None & $21.0916^{* *}$ & 0.0384 \\
& At most one & 2.8721 & 0.6049 \\
\hline GR. SP & None & 14.7411 & 0.2416 \\
& At most one & 2.6170 & 0.6544 \\
\hline IE. IT & None & 12.6781 & 0.3901 \\
& At most one & 1.2744 & 0.9118 \\
\hline IE. PT & None & 10.2764 & 0.6127 \\
& At most one & 1.7622 & 0.8244 \\
\hline IE. SP & None & 9.6706 & 0.6721 \\
& At most one & 1.0393 & 0.9464 \\
\hline IT. PT & None & 9.2582 & 0.7119 \\
& At most one & 1.8854 & 0.8004 \\
\hline IT. SP & None & 13.5751 & 0.3197 \\
& At most one & 2.7382 & 0.6307 \\
\hline PT. SP & None & 15.5181 & 0.1981 \\
& At most one & 2.9255 & 0.5947 \\
\hline & & & \\
\hline & & & \\
\hline
\end{tabular}

Notes:

* and $* *$ denote rejection of the hypothesis at the $1 \%$ and $5 \%$ level, respectively.

MacKinnon et al. (1999)'s p-values.

GR, IE, IT, PT and SP stand for Greece, Ireland, Italy, Portugal and Spain, respectively. 
Table 5. FPE statistics for the whole sample

\begin{tabular}{|c|c|c|c|}
\hline & FPE(m.0) $\times 10^{-3}$ & FPE(m.n) $\times 10^{-3}$ & Causality \\
\hline GR $\rightarrow$ IE & $3.4311(1.0)$ & $3.3972(1.1)$ & Yes \\
\hline IE $\rightarrow$ GR & $13.1864(4.0)$ & $12.8586(4.4)$ & Yes \\
\hline GR $\rightarrow$ IT & $1.6707(1.0)$ & $1.6695(1.1)$ & Yes \\
\hline IT $\rightarrow$ GR & $13.1864(4.0)$ & $13.0770(4.1)$ & Yes \\
\hline $\mathbf{G R} \rightarrow \mathbf{P T}$ & $3.5423(4.0)$ & $3.5096(4.1)$ & Yes \\
\hline PT $\rightarrow$ GR & $13.1864(4.0)$ & $12.6075(4.4)$ & Yes \\
\hline GR $\rightarrow$ SP & $1.9055(4.0)$ & $1.9063(4.1)$ & No \\
\hline SP $\rightarrow$ GR & $13.1864(4.0)$ & $13.1102(4.4)$ & Yes \\
\hline IE $\rightarrow$ IT & $1.6910(1.0)$ & $1.6586(1.1)$ & Yes \\
\hline IT $\rightarrow$ IE & $3.2584(1.0)$ & 3.2596 (1.1) & No \\
\hline IE $\rightarrow$ PT & $3.8007(4.0)$ & $3.6855(4.1)$ & Yes \\
\hline PT $\rightarrow$ IE & $3.2584(1.0)$ & $3.2602(1.1)$ & No \\
\hline IE $\rightarrow$ SP & $1.9248(4.0)$ & $1.8941(4.1)$ & Yes \\
\hline $\mathrm{SP} \rightarrow \mathrm{IE}$ & $3.2584(1.0)$ & $1.9248(1.4)$ & Yes \\
\hline IT $\rightarrow$ PT & $3.8007(4.0)$ & $3.7989(4.1)$ & Yes \\
\hline PT $\rightarrow$ IT & $1.6910(1.0)$ & $1.6812(1.1)$ & Yes \\
\hline IT $\rightarrow$ SP & $1.9248(4.0)$ & $1.9214(4.1)$ & Yes \\
\hline $\mathrm{SP} \rightarrow \mathrm{IT}$ & $1.6910(1.0)$ & $1.6878(1.1)$ & Yes \\
\hline PT $\rightarrow$ SP & $1.9248(4.0)$ & $1.9183(4.1)$ & Yes \\
\hline $\mathbf{S P} \rightarrow$ PT & $3.8007(4.0)$ & $3.7832(4.11)$ & Yes \\
\hline
\end{tabular}

Notes:

The figures in brackets are the optimum order of lags in each pair of countries

GR, IE, IT, PT and SP stand for Greece, Ireland, Italy, Portugal and Spain, respectively. 
Table 6. Domestic Debt Securities; Public Sector Amounts Outstanding (billions US dollars)

\begin{tabular}{|c|c|c|c|c|c|c|c|c|c|c|c|c|c|}
\hline & 1999 & 2000 & 2001 & 2002 & 2003 & 2004 & 2005 & 2006 & 2007 & 2008 & 2009 & 2010 & $\begin{array}{c}\mathbf{2} 010 \\
\% \text { over } \\
\text { EMU }\end{array}$ \\
\hline Finland & 67.60 & 58.69 & 54.06 & 62.59 & 72.57 & 81.03 & 67.92 & 75.42 & 80.90 & 74.30 & 91.38 & 100.26 & $1.2 \%$ \\
\hline Ireland & 23.74 & 20.27 & 17.30 & 23.41 & 35.53 & 42.58 & 36.94 & 41.08 & 45.56 & 58.26 & 121.04 & 129.70 & $1.5 \%$ \\
\hline Portugal & 49.71 & 47.59 & 49.81 & 64.70 & 82.85 & 97.68 & 99.64 & 118.45 & 136.16 & 142.26 & 169.67 & 186.44 & $2.2 \%$ \\
\hline Austria & 108.92 & 108.75 & 108.35 & 133.47 & 165.09 & 181.25 & 163.83 & 191.07 & 219.48 & 219.85 & 242.72 & 239.75 & $2.8 \%$ \\
\hline Greece & 90.17 & 91.77 & 96.11 & 129.32 & 175.06 & 216.32 & 206.58 & 244.31 & 298.61 & 339.63 & 407.85 & 382.65 & $4.5 \%$ \\
\hline Netherlands & 182.96 & 165.30 & 159.49 & 198.35 & 257.05 & 293.31 & 260.16 & 278.85 & 307.63 & 394.85 & 389.44 & 392.97 & $4.6 \%$ \\
\hline Belgium & 251.03 & 235.42 & 229.07 & 276.36 & 328.65 & 351.19 & 308.97 & 343.23 & 398.58 & 408.31 & 442.34 & 437.86 & $5.1 \%$ \\
\hline Spain & 304.83 & 294.58 & 283.19 & 346.62 & 418.28 & 461.64 & 408.49 & 451.58 & 497.56 & 542.91 & 746.11 & 795.72 & $9.3 \%$ \\
\hline France & 624.01 & 606.14 & 609.95 & 787.66 & 1055.80 & 1235.76 & 1141.28 & 1276.15 & 1487.32 & 1540.61 & 1821.81 & 1819.94 & $21.2 \%$ \\
\hline Germany & 754.03 & 726.08 & 705.14 & 911.60 & 1183.52 & 1379.75 & 1272.63 & 1493.82 & 1716.99 & 1662.60 & 1870.40 & 2039.98 & $23.7 \%$ \\
\hline Italy & 1102.49 & 1040.50 & 1015.76 & 1209.14 & 1471.05 & 1637.30 & 1468.59 & 1689.94 & 1928.08 & 1920.20 & 2114.23 & 2069.18 & $24.1 \%$ \\
\hline EMU & 3559.48 & 3395.09 & 3328.23 & 4143.23 & 5245.44 & 5977.80 & 5435.04 & 6203.89 & 7116.87 & 7303.77 & 8416.99 & 8594.42 & $100.0 \%$ \\
\hline
\end{tabular}

Source: This table has been constructed from data collected from Table 18 of BIS Debt securities statistics. 
Table 7. Debt-to-GDP by sector.

\begin{tabular}{|c|c|c|c|c|c|c|c|c|c|c|c|c|}
\hline GREECE & 2002 & 2003 & 2004 & 2005 & 2006 & 2007 & 2008 & 2009 & 2010 & $\begin{array}{c}\text { Average 2002-06 } \\
\text { (I) }\end{array}$ & $\begin{array}{l}\text { Average 2007-10 } \\
\text { (II) }\end{array}$ & $\begin{array}{c}\% \\
\text { (II)/(I) }\end{array}$ \\
\hline Banks & 24.6 & 26.0 & 25.5 & 28.4 & 33.7 & 48.4 & 63.2 & 68.5 & 97.6 & 27.6 & 69.4 & $151 \%$ \\
\hline Households & 19.5 & 22.6 & 27.0 & 32.6 & 37.0 & 40.4 & 40.8 & 41.5 & 59.9 & 35.7 & 45.6 & $28 \%$ \\
\hline Non-financial corporations & 32.6 & 33.2 & 34.0 & 37.5 & 39.0 & 43.1 & 50.9 & 48.0 & 53.0 & 41.3 & 48.8 & $18 \%$ \\
\hline General Government & 101.7 & 97.4 & 98.9 & 109.0 & 106.4 & 105.4 & 110.7 & 127.1 & 142.8 & 111.0 & 121.5 & $9 \%$ \\
\hline IRELAND & 2002 & 2003 & 2004 & 2005 & 2006 & 2007 & 2008 & 2009 & 2010 & $\begin{array}{c}\text { Average 2002-06 } \\
\text { (I) }\end{array}$ & $\begin{array}{c}\text { Average 2007-10 } \\
\text { (II) }\end{array}$ & $\begin{array}{c}\% \\
\text { (II)/(I) }\end{array}$ \\
\hline Banks & 287.1 & 329.0 & 399.3 & 491.9 & 579.6 & 609.7 & 726.1 & 753.6 & 729.1 & 417.4 & 704.6 & $69 \%$ \\
\hline Households & 43.9 & 48.5 & 60.9 & 70.9 & 77.8 & 81.2 & 84.8 & 92.3 & 89.5 & 72.2 & 86.9 & $20 \%$ \\
\hline Non-financial corporations & 40.2 & 44.0 & 55.4 & 63.6 & 79.9 & 91.3 & 105.9 & 107.2 & 72.0 & 73.3 & 94.1 & $28 \%$ \\
\hline General Government & 30.7 & 31.0 & 29.5 & 27.4 & 24.8 & 25.0 & 44.4 & 65.6 & 96.2 & 41.6 & 57.8 & $39 \%$ \\
\hline ITALY & 2002 & 2003 & 2004 & 2005 & 2006 & 2007 & 2008 & 2009 & 2010 & $\begin{array}{c}\text { Average 2002-06 } \\
\text { (I) }\end{array}$ & $\begin{array}{c}\text { Average 2007-10 } \\
\text { (II) }\end{array}$ & $\begin{array}{c}\% \\
\text { (II)/(I) }\end{array}$ \\
\hline Banks & 65.5 & 69.4 & 71.9 & 77.1 & 85.6 & 94.1 & 104.1 & 105.9 & 104.3 & 73.9 & 102.1 & $38 \%$ \\
\hline Households & 21.5 & 23.0 & 25.1 & 27.0 & 28.5 & 29.8 & 30.3 & 32.7 & 38.1 & 28.4 & 32.7 & $15 \%$ \\
\hline Non-financial corporations & 44.4 & 46.4 & 47.4 & 48.0 & 51.7 & 56.8 & 60.9 & 61.7 & 62.3 & 53.3 & 60.4 & $13 \%$ \\
\hline General Government & 105.7 & 104.4 & 103.9 & 105.9 & 106.6 & 103.6 & 106.3 & 116.1 & 119.0 & 107.9 & 111.3 & $3 \%$ \\
\hline PORTUGAL & 2002 & 2003 & 2004 & 2005 & 2006 & 2007 & 2008 & 2009 & 2010 & $\begin{array}{l}\text { Average 2002-06 } \\
\text { (I) }\end{array}$ & $\begin{array}{c}\text { Average 2007-10 } \\
\text { (II) }\end{array}$ & $\begin{array}{c}\% \\
\text { (II)/(I) }\end{array}$ \\
\hline Banks & 106.3 & 113.3 & 101.6 & 103.8 & 115.3 & 126.4 & 136.6 & 156.3 & 182.5 & 108.1 & 150.4 & $39 \%$ \\
\hline Households & 59.3 & 58.6 & 60.4 & 64.5 & 70.7 & 74.5 & 78.3 & 81.7 & 82.3 & 70.0 & 79.2 & $13 \%$ \\
\hline Non-financial corporations & 68.2 & 67.9 & 67.2 & 70.8 & 72.7 & 78.7 & 90.8 & 93.0 & 90.6 & 77.8 & 88.3 & $14 \%$ \\
\hline General Government & 53.8 & 55.9 & 57.6 & 62.8 & 69.5 & 68.3 & 71.6 & 83.0 & 93.0 & 68.4 & 79.0 & $15 \%$ \\
\hline SPAIN & 2002 & 2003 & 2004 & 2005 & 2006 & 2007 & 2008 & 2009 & 2010 & $\begin{array}{c}\text { Average 2002-06 } \\
\text { (I) }\end{array}$ & $\begin{array}{l}\text { Average 2007-10 } \\
\text { (II) }\end{array}$ & $\begin{array}{c}\% \\
\text { (II)/(I) }\end{array}$ \\
\hline Banks & 72.4 & 78.5 & 84.7 & 107.3 & 116.9 & 133.7 & 150.1 & 161.4 & 159.2 & 92.0 & 151.1 & $64 \%$ \\
\hline Households & 47.5 & 51.1 & 55.8 & 66.4 & 74.2 & 78.3 & 81.9 & 83.5 & 82.1 & 69.0 & 81.4 & $18 \%$ \\
\hline Non-financial corporations & 47.1 & 49.6 & 53.8 & 63.0 & 76.3 & 85.5 & 91.2 & 90.4 & 87.0 & 71.6 & 88.5 & $24 \%$ \\
\hline General Government & 52.5 & 48.7 & 46.2 & 43.0 & 39.6 & 36.1 & 39.8 & 53.3 & 60.1 & 46.6 & 47.3 & $2 \%$ \\
\hline
\end{tabular}

Note: Debt-to-GDP at the end of each year.

Source: Eurostat, Monetary Financial Institutions (MFIs) balance sheets obtained from the European Central Bank and authors' estimates. 
Table 8. Foreign banks' claims on individual countries-to-GDP by sector.

\begin{tabular}{|c|c|c|c|c|c|c|c|}
\hline \multicolumn{7}{|c|}{ Foreign banks' claims on public sector debt/GDP } & \multirow[b]{2}{*}{ Average } \\
\hline & 2005 & 2006 & 2007 & 2008 & 2009 & 2010 & \\
\hline GREECE & 30.79 & 33.64 & 36.07 & 30.56 & 29.93 & 17.64 & 29.77 \\
\hline IRELAND & 4.78 & 6.19 & 7.56 & 8.37 & 15.19 & 11.69 & 8.96 \\
\hline ITALY & 20.59 & 21.55 & 23.24 & 21.45 & 24.05 & 13.07 & 20.66 \\
\hline PORTUGAL & 19.47 & 22.03 & 20.61 & 20.60 & 24.00 & 12.68 & 19.90 \\
\hline SPAIN & 8.46 & 8.86 & 8.16 & 7.50 & 9.21 & 6.73 & 8.15 \\
\hline \multicolumn{8}{|c|}{ Foreign banks' claims on banks debt/GDP } \\
\hline & 2005 & 2006 & 2007 & 2008 & 2009 & 2010 & Average \\
\hline GREECE & 6.23 & 7.02 & 10.04 & 12.17 & 10.33 & 3.55 & 8.23 \\
\hline IRELAND & 103.93 & 120.21 & 140.62 & 100.51 & 92.71 & 51.09 & 101.51 \\
\hline ITALY & 10.85 & 12.87 & 14.97 & 11.03 & 9.46 & 7.38 & 11.09 \\
\hline PORTUGAL & 15.77 & 19.14 & 23.58 & 19.71 & 21.08 & 15.88 & 19.19 \\
\hline SPAIN & 16.72 & 20.78 & 26.61 & 23.51 & 23.03 & 14.91 & 20.93 \\
\hline \multicolumn{8}{|c|}{ Foreign banks' claims on non-financial private sector debt/GDP } \\
\hline & 2005 & 2006 & 2007 & 2008 & 2009 & 2010 & Average \\
\hline GREECE & 16.73 & 27.42 & 35.73 & 36.01 & 26.07 & 26.22 & 28.03 \\
\hline IRELAND & 133.91 & 177.50 & 251.16 & 269.12 & 252.07 & 213.98 & 216.29 \\
\hline ITALY & 11.60 & 20.67 & 28.28 & 23.07 & 24.97 & 22.83 & 21.90 \\
\hline PORTUGAL & 32.12 & 38.35 & 46.84 & 46.22 & 49.83 & 45.57 & 43.15 \\
\hline SPAIN & 17.38 & 25.38 & 33.61 & 29.83 & 30.52 & 25.09 & 26.97 \\
\hline
\end{tabular}

Note: Reliance on foreign bank financing is measured by the consolidated claims on an immediate borrower basis of Bank for International Settlements (BIS) reporting banks on each sector (public, banks and non-financial corporations as a proportion of GDP). Data correspond to the end of each year.

Source: This table has been constructed from data collected from Table 9C of BIS Consolidated banking statistics and the OECD. 
Table 9. Claims by nationality of reporting banks as a proportion of total foreign claims.

\begin{tabular}{|c|c|c|c|c|c|c|c|}
\hline GREECE & 2005 & 2006 & 2007 & 2008 & 2009 & 2010 & Average \\
\hline Austrian banks & 3.3 & 2.8 & 2.4 & 2.1 & 2.2 & 2.3 & 2.5 \\
\hline Belgian banks & 8.7 & 5.6 & 5.7 & 3.8 & 2.0 & 1.3 & 4.5 \\
\hline Finnish banks & 0.0 & 0.0 & 0.0 & 0.0 & 0.0 & 0.0 & 0.0 \\
\hline French banks & 9.4 & 19.1 & 24.4 & 28.4 & 36.7 & 39.6 & 26.2 \\
\hline German banks & 22.0 & 18.1 & 15.9 & 14.5 & 20.9 & 23.7 & 19.2 \\
\hline Irish banks & 0.0 & 5.6 & 3.6 & 3.2 & 4.0 & 0.6 & 2.8 \\
\hline Italian banks & 2.2 & 0.0 & 4.3 & 3.6 & 3.2 & 2.9 & 2.7 \\
\hline Dutch banks & 11.3 & 8.8 & 7.9 & 4.9 & 5.7 & 3.5 & 7.0 \\
\hline Portuguese banks & 1.9 & 2.3 & 2.5 & 2.4 & 4.6 & 7.2 & 3.5 \\
\hline Spanish banks & 0.6 & 0.3 & 0.4 & 0.4 & 0.6 & 0.7 & 0.5 \\
\hline British banks & 5.4 & 4.6 & 5.5 & 4.8 & 7.1 & 9.8 & 6.2 \\
\hline US banks & 5.0 & 4.1 & 3.4 & 2.6 & 7.7 & 5.1 & 4.6 \\
\hline Others & 30.3 & 28.7 & 24.0 & 29.3 & 5.4 & 3.3 & 20.2 \\
\hline IRELAND & 2005 & 2006 & 2007 & 2008 & 2009 & 2010 & Average \\
\hline Austrian banks & 1.22 & 1.39 & 1.16 & 0.76 & 1.27 & 0.64 & 1.1 \\
\hline Belgian banks & 8.82 & 10.52 & 8.42 & 6.75 & 5.68 & 5.62 & 7.6 \\
\hline Finnish banks & 0.00 & 0.00 & 0.00 & 0.00 & 0.00 & 0.16 & 0.0 \\
\hline French banks & 7.30 & 9.06 & 12.02 & 10.10 & 8.47 & 6.55 & 8.9 \\
\hline German banks & 25.78 & 23.95 & 25.90 & 29.97 & 29.88 & 26.13 & 26.9 \\
\hline Greek banks & 0.22 & 0.12 & 0.07 & 0.05 & 0.10 & 0.11 & 0.1 \\
\hline Italian banks & 3.71 & 2.96 & 3.43 & 3.62 & 2.83 & 2.99 & 3.3 \\
\hline Dutch banks & 9.92 & 7.49 & 5.69 & 5.25 & 4.58 & 3.70 & 6.1 \\
\hline Portuguese banks & 0.52 & 0.75 & 0.40 & 0.56 & 0.76 & 1.14 & 0.7 \\
\hline Spanish banks & 3.11 & 3.81 & 3.04 & 2.20 & 2.38 & 2.22 & 2.8 \\
\hline British banks & 26.49 & 26.91 & 26.21 & 28.22 & 27.12 & 29.91 & 27.5 \\
\hline US banks & 3.15 & 3.97 & 4.51 & 4.89 & 9.28 & 11.27 & 6.2 \\
\hline Others & 9.77 & 9.07 & 9.15 & 7.63 & 7.67 & 9.57 & 8.8 \\
\hline PORTUGAL & 2005 & 2006 & 2007 & 2008 & 2009 & 2010 & Average \\
\hline Austrian banks & 1.39 & 1.31 & 1.09 & 1.11 & 1.15 & 0.81 & 1.1 \\
\hline Belgian banks & 5.14 & 6.65 & 4.77 & 5.28 & 2.33 & 1.75 & 4.3 \\
\hline Finnish banks & 0.00 & 0.00 & 0.00 & 0.00 & 0.00 & 0.19 & 0.0 \\
\hline French banks & 10.28 & 10.55 & 13.79 & 13.11 & 17.83 & 13.33 & 13.1 \\
\hline German banks & 20.64 & 19.27 & 20.05 & 19.50 & 18.79 & 18.03 & 19.4 \\
\hline Greek banks & 0.02 & 0.01 & 0.02 & 0.02 & 0.05 & 0.04 & 0.0 \\
\hline Irish banks & 0.00 & 4.30 & 3.62 & 2.78 & 2.16 & 1.35 & 2.4 \\
\hline Italian banks & 3.18 & 3.83 & 3.39 & 2.72 & 2.66 & 2.01 & 3.0 \\
\hline Dutch banks & 7.45 & 6.66 & 7.39 & 6.07 & 5.61 & 3.24 & 6.1 \\
\hline Spanish banks & 35.12 & 31.99 & 32.23 & 33.93 & 33.71 & 41.89 & 34.8 \\
\hline British banks & 11.17 & 8.68 & 8.55 & 9.62 & 10.20 & 12.05 & 10.0 \\
\hline US banks & 1.64 & 2.26 & 1.51 & 0.81 & 1.85 & 2.61 & 1.8 \\
\hline Others & 3.98 & 4.50 & 3.60 & 5.05 & 3.66 & 2.70 & 3.9 \\
\hline SPAIN & 2005 & 2006 & 2007 & 2008 & 2009 & 2010 & Average \\
\hline Austrian banks & 0.86 & 0.87 & 0.82 & 0.87 & 0.96 & 0.95 & 0.9 \\
\hline Belgian banks & 4.22 & 4.52 & 4.44 & 4.82 & 2.46 & 3.06 & 3.9 \\
\hline Finnish banks & 0.00 & 0.00 & 0.00 & 0.00 & 0.00 & 0.22 & 0.0 \\
\hline French banks & 18.25 & 14.94 & 18.92 & 19.35 & 22.97 & 20.01 & 19.1 \\
\hline German banks & 26.51 & 30.07 & 29.23 & 27.83 & 25.89 & 25.88 & 27.6 \\
\hline Greek banks & 0.06 & 0.01 & 0.01 & 0.03 & 0.04 & 0.05 & 0.0 \\
\hline Irish banks & 0.00 & 3.86 & 3.84 & 3.70 & 3.45 & 2.13 & 2.8 \\
\hline Italian banks & 2.49 & 2.34 & 2.70 & 3.12 & 3.39 & 4.22 & 3.0 \\
\hline Dutch banks & 16.87 & 13.95 & 13.36 & 13.69 & 13.02 & 10.94 & 13.6 \\
\hline Portugal banks & 2.61 & 2.84 & 2.77 & 3.14 & 3.14 & 3.80 & 3.0 \\
\hline British banks & 15.23 & 13.84 & 12.55 & 13.66 & 11.98 & 15.25 & 13.8 \\
\hline US banks & 4.55 & 4.72 & 4.12 & 3.67 & 6.31 & 6.72 & 5.0 \\
\hline Others & 8.35 & 8.02 & 7.25 & 6.12 & 6.37 & 6.78 & 7.1 \\
\hline ITALY & 2005 & 2006 & 2007 & 2008 & 2009 & 2010 & Average \\
\hline Austrian banks & 2.64 & 2.19 & 2.04 & 1.61 & 2.23 & 2.58 & 2.2 \\
\hline Belgian banks & 10.85 & 8.09 & 4.38 & 4.74 & 2.83 & 2.99 & 5.6 \\
\hline Finnish banks & 0.00 & 0.00 & 0.00 & 0.00 & 0.00 & 0.08 & 0.0 \\
\hline French banks & 18.94 & 27.45 & 37.66 & 42.79 & 44.44 & 45.53 & 36.1 \\
\hline German banks & 25.26 & 20.10 & 19.41 & 18.91 & 16.60 & 18.82 & 19.9 \\
\hline Greek banks & 0.15 & 0.07 & 0.02 & 0.03 & 0.06 & 0.07 & 0.1 \\
\hline Irish banks & 0.00 & 5.20 & 3.94 & 4.25 & 3.99 & 1.53 & 3.2 \\
\hline Dutch banks & 10.84 & 13.82 & 11.65 & 6.11 & 6.04 & 5.26 & 9.0 \\
\hline Portuguese banks & 0.76 & 0.75 & 0.41 & 0.32 & 0.47 & 0.35 & 0.5 \\
\hline Spanish banks & 4.44 & 2.99 & 2.82 & 4.44 & 4.13 & 3.62 & 3.7 \\
\hline British banks & 9.22 & 7.02 & 7.09 & 6.83 & 6.71 & 7.70 & 7.4 \\
\hline US banks & 5.78 & 3.25 & 2.79 & 2.33 & 4.66 & 4.26 & 3.8 \\
\hline Others & 11.12 & 9.08 & 7.78 & 7.65 & 7.84 & 7.21 & 8.4 \\
\hline
\end{tabular}

Note: This table displays the consolidated claims on an immediate borrower basis of Bank for International Settlements (BIS) by nationality of reporting banks as a proportion of total foreign claims on each country. Data correspond to the end of each year.

Source: This table has been constructed from data collected from Table 9D of BIS Consolidated banking statistics 
Table 10a: Probit models, causal relationships running from Greece

\begin{tabular}{|c|c|c|c|c|c|c|c|}
\hline \multicolumn{2}{|c|}{ GREECE $\rightarrow$ IRELAND } & \multicolumn{2}{|c|}{ GREECE $\rightarrow$ ITALY } & \multicolumn{2}{|c|}{ GREECE $\rightarrow$ PORTUGAL } & \multicolumn{2}{|c|}{ GREECE $\rightarrow$ SPAIN } \\
\hline Constant & - & Constant & $\begin{array}{l}3.6366 \\
(2.9731) \\
\end{array}$ & Constant & $\begin{array}{c}8.2950 \\
(2.7206) \\
\end{array}$ & Constant & $\begin{array}{c}3.8909 \\
(2.6997) \\
\end{array}$ \\
\hline GRIEBAN & $\begin{array}{c}3.0647 \\
(2.9132) \\
{[0.4567]} \\
\end{array}$ & GRITBAN & $\begin{array}{c}7.2099 \\
(2.8625) \\
{[0.5504]}\end{array}$ & GRPTBAN & $\begin{array}{l}16.6843 \\
(2.9053) \\
{[0.7940]}\end{array}$ & GRSPBAN & $\begin{array}{l}13.2210 \\
(2.8541) \\
{[0.5983]}\end{array}$ \\
\hline DEFIE & $\begin{array}{c}0.1700 \\
(2.6513) \\
{[0.0253]}\end{array}$ & - & - & & - & DEFSP & $\begin{array}{c}0.3204 \\
(2.9172) \\
{[0.0145]}\end{array}$ \\
\hline GRGOVDEB & $\begin{array}{c}0.1262 \\
(2.8591) \\
{[0.0188]}\end{array}$ & GRGOVDEB & $\begin{array}{c}7.7571 \\
(2.7749) \\
{[0.5922]}\end{array}$ & GRGOVDEB & $\begin{array}{c}2.9152 \\
(2.8010) \\
{[0.1387]} \\
\end{array}$ & GRGOVDEB & $\begin{array}{c}1.9722 \\
(2.8539) \\
{[0.0893]}\end{array}$ \\
\hline GRBANDEB & $\begin{array}{c}0.2986 \\
(2.8522) \\
{[0.0445]}\end{array}$ & - & - & & - & - & - \\
\hline- & - & - & - & GRNFIDEB & $\begin{array}{c}2.2784 \\
(2.7981) \\
{[0.1084]}\end{array}$ & - & - \\
\hline- & - & - & - & GRPUB & $\begin{array}{c}2.4814 \\
(3.9466) \\
{[0.1181]}\end{array}$ & - & - \\
\hline- & - & - & - & GRPRI & $\begin{array}{c}9.9372 \\
(2.8645) \\
{[0.4729]}\end{array}$ & - & - \\
\hline IEBAN & $\begin{array}{c}0.0930 \\
(2.8260) \\
{[0.0139]}\end{array}$ & - & - & - & - & - & - \\
\hline IEPRI & $\begin{array}{c}0.0571 \\
(2.8762) \\
{[0.0085]}\end{array}$ & - & - & - & - & - & - \\
\hline- & - & INFGR & $\begin{array}{l}4.3869 \\
(2.8793) \\
{[0.3349]}\end{array}$ & INFGR & $\begin{array}{c}3.4490 \\
(2.8622) \\
{[0.1641]}\end{array}$ & - & - \\
\hline UGR & $\begin{array}{c}1.7894 \\
(2.9685) \\
{[0.2675]}\end{array}$ & UGR & $\begin{array}{l}7.2370 \\
(2.8365) \\
{[0.5525]}\end{array}$ & UGR & $\begin{array}{l}13.6705 \\
(2.8451) \\
{[0.6506]}\end{array}$ & UGR & $\begin{array}{r}9.8748 \\
(2.8737) \\
{[0.4469]}\end{array}$ \\
\hline- & - & RATGR & $\begin{array}{c}0.8469 \\
(2.8778) \\
{[0.0646]}\end{array}$ & - & - & - & - \\
\hline- & - & - & 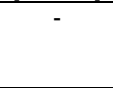 & RATPT & $\begin{array}{c}2.7325 \\
(2.7830) \\
{[0.1301]}\end{array}$ & - & - \\
\hline GRLIQ & $\begin{array}{c}0.0498 \\
(2.9134) \\
{[0.0074]}\end{array}$ & GRLIQ & $\begin{array}{c}0.3215 \\
(2.8754) \\
{[0.0245]}\end{array}$ & GRLIQ & $\begin{array}{c}0.2481 \\
(2.9163) \\
{[0.0116]}\end{array}$ & GRLIQ & $\begin{array}{c}0.2108 \\
(2.8415) \\
{[0.0095]}\end{array}$ \\
\hline IELIQ & $\begin{array}{c}0.0594 \\
(2.8647) \\
{[0.0088]}\end{array}$ & ITLIQ & $\begin{array}{c}-0.3774 \\
(-2.8339) \\
{[-0.0288]}\end{array}$ & PTLIQ & $\begin{array}{c}0.4957 \\
(2.9542) \\
{[0.0236]}\end{array}$ & SPLIQ & $\begin{array}{c}0.3296 \\
(2.8325) \\
{[0.0149]}\end{array}$ \\
\hline RISK & $\begin{array}{c}0.1858 \\
(2.8558) \\
{[0.0277]}\end{array}$ & RISK & $\begin{array}{c}4.9026 \\
(2.8539) \\
{[0.3743]}\end{array}$ & RISK & $\begin{array}{l}7.1002 \\
(2.9081) \\
{[0.3379]}\end{array}$ & RISK & $\begin{array}{l}7.3125 \\
(2.8743) \\
{[0.3309]}\end{array}$ \\
\hline McFadden R-squared & 0.6994 & McFadden R-squared & 0.9054 & McFadden R-squared & 0.9104 & McFadden R-squared & 0.9115 \\
\hline
\end{tabular}


Table 10b: Probit models, causal relationships running from Ireland

\begin{tabular}{|c|c|c|c|c|c|c|c|}
\hline \multicolumn{2}{|c|}{ IRELAND $\rightarrow$ GREECE } & \multicolumn{2}{|c|}{ IRELAND $\rightarrow$ ITALY } & \multicolumn{2}{|c|}{ IRELAND $\rightarrow$ PORTUGAL } & \multicolumn{2}{|c|}{ IRELAND $\rightarrow$ SPAIN } \\
\hline Constant & $\begin{array}{c}-1.5458 \\
(-2.9036)\end{array}$ & Constant & $\begin{array}{c}-2.1732 \\
(-2.7931)\end{array}$ & Constant & $\begin{array}{c}-2.0214 \\
(-2.7722)\end{array}$ & Constant & $\begin{array}{c}1.4966 \\
(2.7134)\end{array}$ \\
\hline IEGRBAN & $\begin{array}{c}6.2617 \\
(2.9434) \\
{[0.6320]}\end{array}$ & IEITBAN & $\begin{array}{c}0.8343 \\
(2.8121) \\
{[0.1063]}\end{array}$ & IEPTBAN & $\begin{array}{l}1.6204 \\
(2.8658) \\
{[0.1676]}\end{array}$ & IESPBAN & $\begin{array}{c}0.8592 \\
(2.9215) \\
{[0.0734]}\end{array}$ \\
\hline DEFIE & $\begin{array}{c}4.0375 \\
(2.8661) \\
{[0.4070]}\end{array}$ & DEFIE & $\begin{array}{c}3.8117 \\
(2.8146) \\
{[0.4858]}\end{array}$ & DEFIE & $\begin{array}{l}0.4748 \\
(2.8015) \\
{[0.0491]}\end{array}$ & DEFIE & $\begin{array}{c}c .0704] \\
0.4998 \\
(2.8376) \\
{[0.0427]}\end{array}$ \\
\hline - & - & - & - & IEGOVDEB & $\begin{array}{l}1.7880 \\
(2.8136) \\
{[0.1850]}\end{array}$ & IEGOVDEB & $\begin{array}{l}2.1163 \\
(2.8114) \\
{[0.1807]}\end{array}$ \\
\hline IEBANDEB & $\begin{array}{l}5.7021 \\
(2.8213) \\
{[0.5755]}\end{array}$ & IEBANDEB & $\begin{array}{l}4.9086 \\
(2.9260) \\
{[0.6256]}\end{array}$ & IEBANDEB & $\begin{array}{l}5.7896 \\
(2.9712) \\
{[0.5989]}\end{array}$ & IEBANDEB & $\begin{array}{c}6.9868 \\
(2.8225) \\
{[0.5966]}\end{array}$ \\
\hline IEPUB & $\begin{array}{c}1.4075 \\
(2.7982) \\
{[0.1421]}\end{array}$ & IEPUB & $\begin{array}{c}1.9070 \\
(2.7941) \\
{[0.2430]}\end{array}$ & IEPUB & $\begin{array}{l}1.2466 \\
(2.8239) \\
{[0.1289]}\end{array}$ & IEPUB & $\begin{array}{l}1.8200 \\
(2.9735) \\
{[0.1554]}\end{array}$ \\
\hline- & - & - & - & IEBAN & $\begin{array}{l}0.0827 \\
(2.8380) \\
{[0.0086]}\end{array}$ & IEBAN & $\begin{array}{c}0.1024] \\
0.4220 \\
(2.8045) \\
{[0.0260]}\end{array}$ \\
\hline- & - & INFIE & $\begin{array}{l}2.5504 \\
(2.8176) \\
\Gamma 0.3250]\end{array}$ & - & - & - & - \\
\hline- & - & - & I0.0L0 & UIE & $\begin{array}{l}6.1241 \\
(2.8143) \\
{[0.6335]}\end{array}$ & - & - \\
\hline- & - & - & - & UPT & $\begin{array}{l}1.8149 \\
(2.8211) \\
{[0.1877]}\end{array}$ & USP & $\begin{array}{c}3.6142 \\
(2.8407) \\
{[0.3086]}\end{array}$ \\
\hline- & - & - & - & CACPT & $\begin{array}{c}-4.2778 \\
(-2.9517) \\
{[-0.4425]}\end{array}$ & - & [0.0000] \\
\hline IELIQ & $\begin{array}{c}0.0211 \\
(2.8178) \\
{[0.0021]}\end{array}$ & IELIQ & $\begin{array}{c}0.2974 \\
(2.7973) \\
{[0.0507]}\end{array}$ & IELIQ & $\begin{array}{l}0.3781 \\
(2.7842) \\
{[0.0391]} \\
\end{array}$ & IELIQ & $\begin{array}{c}0.1026 \\
(2.9114) \\
{[0.0088]} \\
\end{array}$ \\
\hline GRLIQ & $\begin{array}{c}0.0111 \\
(2.8055) \\
{[0.0011]}\end{array}$ & ITLIQ & $\begin{array}{c}-0.1301 \\
(-2.8366) \\
{[-0.0166]}\end{array}$ & PTLIQ & $\begin{array}{l}0.1926 \\
(2.8296) \\
{[0.0199]}\end{array}$ & SPLIQ & $\begin{array}{c}0.0408 \\
(2.8378) \\
{[0.0035]}\end{array}$ \\
\hline RISK & $\begin{array}{l}1.8796 \\
(2.7988) \\
{[0.1897]}\end{array}$ & RISK & $\begin{array}{l}0.7951 \\
(2.8115) \\
{[0.1013]}\end{array}$ & RISK & $\begin{array}{l}1.8934 \\
(2.8411) \\
{[0.1959]}\end{array}$ & RISK & $\begin{array}{c}0.7844 \\
(2.8445) \\
{[0.0670]}\end{array}$ \\
\hline McFadden R-squared & 0.7322 & McFadden R-squared & 0.8697 & McFadden R-squared & 0.8539 & McFadden R-squared & 0.7715 \\
\hline
\end{tabular}


Table 10c: Probit models, causal relationships running from Italy

\begin{tabular}{|c|c|c|c|c|c|c|c|}
\hline \multicolumn{2}{|c|}{ ITALY $\rightarrow$ GREECE } & \multicolumn{2}{|c|}{ ITALY $\rightarrow$ IRELAND } & \multicolumn{2}{|c|}{ ITALY $\rightarrow$ PORTUGAL } & \multicolumn{2}{|c|}{ ITALY $\rightarrow$ SPAIN } \\
\hline Constant & $\begin{array}{c}-147.7035 \\
(-2.7451)\end{array}$ & Constant & $\begin{array}{l}21.6883 \\
(2.7548)\end{array}$ & Constant & $\begin{array}{c}4.3911 \\
(2.9547)\end{array}$ & Constant & $\begin{array}{c}-3.8579 \\
(-2.8161)\end{array}$ \\
\hline ITGRBAN & $\begin{array}{c}6.1091 \\
(2.8083) \\
{[0.3192]}\end{array}$ & ITIEBAN & $\begin{array}{l}5.0801 \\
(2.8373) \\
{[0.6232]}\end{array}$ & ITPTBAN & $\begin{array}{c}c(2.4385 \\
5.8181) \\
{[0.4101]}\end{array}$ & ITSPBAN & $\begin{array}{l}1.6617 \\
(2.8645) \\
{[0.3174]}\end{array}$ \\
\hline DEFIT & $\begin{array}{c}1.2928 \\
(2.8748) \\
{[0.0676]}\end{array}$ & DEFIT & $\begin{array}{c}1.5216 \\
(2.8125) \\
{[0.1867]}\end{array}$ & DEFIT & $\begin{array}{c}0.8830 \\
(2.9155) \\
{[0.0666]}\end{array}$ & DEFIT & $\begin{array}{l}5.2970 \\
(2.9183) \\
{[0.4591]}\end{array}$ \\
\hline- & - & ITGOVDEB & $\begin{array}{c}0.8334 \\
(2.8356) \\
{[0.1022]} \\
\end{array}$ & ITGOVDEB & $\begin{array}{l}2.7902 \\
(2.8157) \\
{[0.2104]}\end{array}$ & ITGOVDEB & $\begin{array}{c}2.6745 \\
(2.8114) \\
{[0.2318]} \\
\end{array}$ \\
\hline ITBANDEB & $\begin{array}{c}0.2461 \\
(2.9777) \\
{[0.0129]}\end{array}$ & ITBANDEB & $\begin{array}{l}2.6303 \\
(2.9111) \\
{[0.3227]}\end{array}$ & - & - & ITBANDEB & $\begin{array}{l}4.6368 \\
(2.7894) \\
{[0.4019]}\end{array}$ \\
\hline ITHOUDEB & $\begin{array}{l}7.6864 \\
(2.7543) \\
{[0.4017]}\end{array}$ & ITHOUDEB & $\begin{array}{c}1.4070 \\
(2.8519) \\
{[0.1726]}\end{array}$ & ITHOUDEB & $\begin{array}{c}2.4669 \\
(2.8112) \\
{[0.1860]}\end{array}$ & - & 2 \\
\hline ITPUB & $\begin{array}{c}4.1310 \\
(2.7449) \\
{[0.2159]}\end{array}$ & - & - & - & - & - & - \\
\hline UIT & $\begin{array}{l}1.4512 \\
(2.8403) \\
{[0.0758]}\end{array}$ & UIT & $\begin{array}{c}2.3506 \\
(2.8992) \\
{[0.2884]}\end{array}$ & UIT & $\begin{array}{l}1.0125 \\
(2.9480) \\
{[0.0764]} \\
\end{array}$ & UIT & $\begin{array}{l}8.9497 \\
(2.7971) \\
{[0.7757]}\end{array}$ \\
\hline- & [0.0.0) & - & - & UPT & $\begin{array}{l}5.2870 \\
(2.7987) \\
{[0.3987]}\end{array}$ & - & 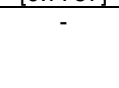 \\
\hline- & & - & - & RATIT & $\begin{array}{l}1.7912 \\
(2.8243) \\
{[0.2104]}\end{array}$ & - & \\
\hline RATGR & $\begin{array}{c}8.3668 \\
(2.9418) \\
{[0.4372]}\end{array}$ & RATIE & $\begin{array}{c}2.2207 \\
(2.7845) \\
{[0.2724]}\end{array}$ & - & {$[0.2101]$} & RATSP & $\begin{array}{c}1.6326 \\
(2.8071) \\
{[0.1415]}\end{array}$ \\
\hline ITLIQ & $\begin{array}{c}-0.0324 \\
(-2.7489) \\
{[-0.0017]}\end{array}$ & ITLIQ & $\begin{array}{c}-0.0084 \\
(-2.8410) \\
{[-0.0010]}\end{array}$ & ITLIQ & $\begin{array}{c}-0.0358 \\
(-2.8412) \\
{[-0.0027]}\end{array}$ & ITLIQ & $\begin{array}{c}-0.6509 \\
(-2.8102) \\
{[-0.0564]}\end{array}$ \\
\hline GRLIQ & $\begin{array}{c}0.1953 \\
(2.9683) \\
{[0.0102]} \\
\end{array}$ & IELIQ & $\begin{array}{c}0.0772 \\
(2.8384) \\
{[0.0095]}\end{array}$ & PTLIQ & $\begin{array}{c}0.0499 \\
(2.7967) \\
{[0.0038]}\end{array}$ & SPLIQ & $\begin{array}{l}0.3262 \\
(2.8491) \\
{[0.0283]}\end{array}$ \\
\hline RISK & $\begin{array}{l}0.1848 \\
(2.8257) \\
{[0.0097]}\end{array}$ & RISK & $\begin{array}{c}0.2846 \\
(2.7947) \\
{[0.0346]}\end{array}$ & RISK & $\begin{array}{l}1.1016 \\
(2.8102) \\
{[0.0831]}\end{array}$ & RISK & $\begin{array}{l}5.1443 \\
(2.7911) \\
{[0.4459]}\end{array}$ \\
\hline McFadden R-squared & $\frac{0.7395}{0.7395}$ & McFadden R-squared & 0.8896 & McFadden R-squared & 0.8404 & McFadden R-squared & 0.8012 \\
\hline
\end{tabular}


Table 10d: Probit models, causal relationships running from Portugal

\begin{tabular}{|c|c|c|c|c|c|c|c|}
\hline \multicolumn{2}{|c|}{ PORTUGAL $\rightarrow$ GREECE } & \multicolumn{2}{|c|}{ PORTUGAL $\rightarrow$ IRELAND } & \multicolumn{2}{|c|}{ PORTUGAL $\rightarrow$ ITALY } & \multicolumn{2}{|c|}{ PORTUGAL $\rightarrow$ SPAIN } \\
\hline Constant & $\begin{array}{l}-10.7104 \\
(-2.7990) \\
\end{array}$ & Constant & $\begin{array}{l}21.9866 \\
(2.7645) \\
\end{array}$ & Constant & $\begin{array}{c}-8.8861 \\
(-2.7831) \\
\end{array}$ & Constant & - \\
\hline PTGRBAN & $\begin{array}{c}6.8649 \\
(2.9412) \\
{[0.5115]} \\
\end{array}$ & PTIEBAN & $\begin{array}{l}5.8230 \\
(2.8312) \\
{[0.4820]} \\
\end{array}$ & PTITBAN & $\begin{array}{c}5.8690 \\
(2.9051) \\
{[0.5057]} \\
\end{array}$ & PTSPBAN & $\begin{array}{c}1.5364 \\
(2.8966) \\
{[0.6624]} \\
\end{array}$ \\
\hline DEFPT & $\begin{array}{c}0.5226 \\
(2.7988) \\
{[0.0389]}\end{array}$ & DEFPT & $\begin{array}{l}1.4552 \\
(2.8802) \\
{[0.1204]}\end{array}$ & DEFPT & $\begin{array}{c}1.3031 \\
(2.9124) \\
{[0.1123]}\end{array}$ & DEFPT & $\begin{array}{r}1.4371 \\
(2.8211) \\
{[0.6197]}\end{array}$ \\
\hline- & - & - & - & PTGOVDEB & $\begin{array}{c}1.1837 \\
(2.7761) \\
{[0.1020]} \\
\end{array}$ & - & - \\
\hline- & 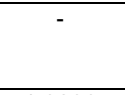 & IEGOVDEB & $\begin{array}{c}0.6317 \\
(2.8561) \\
{[0.0523]}\end{array}$ & - & - & SPGOVDEB & $\begin{array}{c}1.1157 \\
(2.7898) \\
{[0.4811]}\end{array}$ \\
\hline PTNFIDEB & $\begin{array}{c}1.3836 \\
(2.8721) \\
{[0.1031]}\end{array}$ & - & - & - & - & - & - \\
\hline PTBANDEB & $\begin{array}{c}1.0106 \\
(2.9308) \\
{[0.0753]} \\
\end{array}$ & - & - & - & - & - & - \\
\hline PTPUB & $\begin{array}{c}1.1303 \\
(2.8740) \\
{[0.0842]}\end{array}$ & - & - & PTPUB & $\begin{array}{c}5.6289 \\
(2.8256) \\
{[0.2466]}\end{array}$ & - & - \\
\hline INFPT & $\begin{array}{c}3.2285 \\
(2.8519) \\
{[0.2405]}\end{array}$ & INFPT & $\begin{array}{c}1.8814 \\
(2.8650) \\
{[0.1557]}\end{array}$ & - & - & INFPT & $\begin{array}{c}0.5534 \\
(2.8221) \\
{[0.2386]} \\
\end{array}$ \\
\hline UPT & $\begin{array}{c}9.3581 \\
(2.8743) \\
{[0.6972]}\end{array}$ & UPT & $\begin{array}{l}1.1380 \\
(2.9154) \\
{[0.0942]}\end{array}$ & UPT & $\begin{array}{c}3.7056 \\
(2.9012) \\
{[0.3193]}\end{array}$ & UPT & $\begin{array}{c}1.2220 \\
(2.7879) \\
{[0.5269]}\end{array}$ \\
\hline- & - & UIE & $\begin{array}{l}1.6690 \\
(2.9314) \\
{[0.1381]}\end{array}$ & UIT & $\begin{array}{c}2.8616 \\
(2.7897) \\
{[0.4850]}\end{array}$ & USP & $\begin{array}{l}1.2273 \\
(2.7956) \\
{[0.5292]}\end{array}$ \\
\hline- & & RATPT & $\begin{array}{l}2.0538 \\
(2.8343) \\
{[0.1699]}\end{array}$ & RATPT & $\begin{array}{c}1.5389 \\
(2.8612) \\
{[0.1326]}\end{array}$ & RATPT & $\begin{array}{c}0.3497 \\
(2.8712) \\
{[0.1508]}\end{array}$ \\
\hline- & - & - & - & RATIT & $\begin{array}{c}2.2728 \\
(2.8067) \\
{[0.1958]}\end{array}$ & - & - \\
\hline PTLIQ & $\begin{array}{c}0.1086 \\
(2.9518) \\
{[0.0089]}\end{array}$ & PTLIQ & $\begin{array}{c}0.0548 \\
(2.8164) \\
{[0.0045]}\end{array}$ & PTLIQ & $\begin{array}{c}0.1844 \\
(2.7740) \\
{[0.0159]}\end{array}$ & PTLIQ & $\begin{array}{c}0.1616 \\
(2.9014) \\
{[0.0697]}\end{array}$ \\
\hline GRLIQ & $\begin{array}{c}0.0173 \\
(2.7986) \\
{[0.0013]}\end{array}$ & IELIQ & $\begin{array}{l}0.1667 \\
(2.9167) \\
{[0.0138]}\end{array}$ & ITLIQ & $\begin{array}{l}-0.3415 \\
(-2.9521) \\
{[-0.0294]}\end{array}$ & SPLIQ & $\begin{array}{l}0.2123 \\
(2.8612) \\
{[0.0916]}\end{array}$ \\
\hline RISK & $\begin{array}{c}0.6213 \\
(2.8648) \\
{[0.0463]} \\
\end{array}$ & RISK & $\begin{array}{l}1.0465 \\
(2.7799) \\
{[0.0866]} \\
\end{array}$ & RISK & $\begin{array}{c}2.3108 \\
(2.8213) \\
{[0.1991]}\end{array}$ & RISK & $\begin{array}{l}1.1060 \\
(2.7863) \\
{[0.4769]} \\
\end{array}$ \\
\hline McFadden R-squared & 0.7705 & McFadden R-squared & 0.8861 & McFadden R-squared & 0.7325 & McFadden R-squared & 0.8948 \\
\hline
\end{tabular}


Table 10e: Probit models, causal relationships running from Spain

\begin{tabular}{|c|c|c|c|c|c|c|c|}
\hline \multicolumn{2}{|c|}{ SPAIN $\rightarrow$ GREECE } & \multicolumn{2}{|c|}{ SPAIN $\rightarrow$ IRELAND } & \multicolumn{2}{|c|}{ SPAIN $\rightarrow$ ITALY } & \multicolumn{2}{|c|}{ SPAIN $\rightarrow$ PORTUGAL } \\
\hline Constant & $\begin{array}{l}-26.1653 \\
(-2.7745)\end{array}$ & Constant & $\begin{array}{l}8.2908 \\
(2.7894)\end{array}$ & Constant & $\begin{array}{c}-2.1144 \\
(-2.7614)\end{array}$ & Constant & $\begin{array}{c}-6.2569 \\
(-2.7625) \\
\end{array}$ \\
\hline SPGRBAN & $\begin{array}{l}5.5165 \\
(2.9035) \\
{[0.2747]} \\
\end{array}$ & SPIEBAN & $\begin{array}{l}2.5361 \\
(2.9103) \\
{[0.2686]} \\
\end{array}$ & SPITBAN & $\begin{array}{c}1.9815 \\
(2.8453) \\
{[0.2029]} \\
\end{array}$ & SPPTBAN & $\begin{array}{l}0.8084 \\
(2.7593) \\
{[0.2591]}\end{array}$ \\
\hline- & - & DEFSP & $\begin{array}{l}3.5618 \\
(2.8191) \\
{[0.3782]}\end{array}$ & DEFSP & $\begin{array}{c}4.5066 \\
(2.7915) \\
{[0.4614]}\end{array}$ & - & - \\
\hline - & & SPGOVDEB & $\begin{array}{l}0.7896 \\
(2.8676) \\
{[0.0838]} \\
\end{array}$ & SPGOVDEB & $\begin{array}{c}5.5866 \\
(2.8121) \\
{[0.5720]} \\
\end{array}$ & - & - \\
\hline SPNFIDEB & $\begin{array}{l}0.9817 \\
(2.8314) \\
{[0.0489]} \\
\end{array}$ & - & - & - & - & SPNFIDEB & $\begin{array}{l}0.1315 \\
(2.8560) \\
{[0.0421]} \\
\end{array}$ \\
\hline SPBANDEB & $\begin{array}{l}2.7065 \\
(2.8451) \\
{[0.1348]} \\
\end{array}$ & SPBANDEB & $\begin{array}{l}0.0938 \\
(2.7988) \\
{[0.0100]}\end{array}$ & - & - & - & $\frac{0.04<1]}{-}$ \\
\hline SPPUB & $\begin{array}{l}8.4892 \\
(2.9176) \\
{[0.4228]}\end{array}$ & - & - & - & - & - & - \\
\hline- & - & SPBAN & $\begin{array}{l}0.7165 \\
(2.8145) \\
{[0.0761]} \\
\end{array}$ & - & - & - & - \\
\hline- & - & - & - & ITPUB & $\begin{array}{l}5.2408 \\
(2.8512) \\
{[0.5366]}\end{array}$ & - & - \\
\hline- & - & USP & $\begin{array}{l}6.8754 \\
(2.7824) \\
{[0.7300]} \\
\end{array}$ & USP & $\begin{array}{c}7.1764 \\
(2.8161) \\
{[0.7347]} \\
\end{array}$ & - & - \\
\hline- & & UIE & $\begin{array}{l}1.5295 \\
(2.9143) \\
{[0.1624]}\end{array}$ & UIT & $\begin{array}{c}4.9746 \\
(2.8013) \\
{[0.5093]}\end{array}$ & UPT & $\begin{array}{c}1.3479 \\
(2.9141) \\
{[0.4319]}\end{array}$ \\
\hline CACSP & $\begin{array}{c}-2.1886 \\
(-2.8547) \\
{[-0.1090]} \\
\end{array}$ & CACSP & $\begin{array}{r}-1.4087 \\
(-2.8104) \\
{[-0.1496]} \\
\end{array}$ & CACSP & $\begin{array}{c}-2.6802 \\
(-2.7978) \\
{[-0.2744]}\end{array}$ & - & - \\
\hline RATSP & $\begin{array}{l}4.8822 \\
(2.8287) \\
{[0.2432]}\end{array}$ & - & - & - & - & - & - \\
\hline RATGR & $\begin{array}{l}1.5694 \\
(2.8295) \\
{[0.0782]}\end{array}$ & - & - & RATIT & $\begin{array}{c}3.7418 \\
(2.8315) \\
{[0.3831]}\end{array}$ & - & - \\
\hline SPLIQ & $\begin{array}{c}0.0325 \\
(2.834) \\
{[0.0016]}\end{array}$ & SPLIQ & $\begin{array}{c}0.0553 \\
(2.8654) \\
{[0.0059]}\end{array}$ & SPLIQ & $\begin{array}{c}0.3724 \\
(2.7986) \\
(0.03811\end{array}$ & SPLIQ & $\begin{array}{c}0.2728 \\
(2.8112) \\
0.08741\end{array}$ \\
\hline GRLIQ & $\begin{array}{l}0.0488 \\
(2.7841) \\
{[0.0021]}\end{array}$ & IELIQ & $\begin{array}{l}0.4745 \\
(2.8710) \\
{[0.0504]}\end{array}$ & ITLIQ & $\begin{array}{c}-0.6138 \\
(-2.9011) \\
{[-0.0628]}\end{array}$ & PTLIQ & $\begin{array}{l}0.1785 \\
(2.8283) \\
{[0.0572]}\end{array}$ \\
\hline RISK & $\begin{array}{l}0.6930 \\
(2.7936) \\
{[0.0345]}\end{array}$ & RISK & $\begin{array}{l}2.0466 \\
(2.7814) \\
{[0.2173]}\end{array}$ & RISK & $\begin{array}{c}2.9255 \\
(2.8576) \\
{[0.2995]}\end{array}$ & RISK & $\begin{array}{l}1.0696 \\
(2.7911) \\
{[0.3428]}\end{array}$ \\
\hline McFadden R-squared & 0.8329 & McFadden R-squared & 0.7922 & McFadden R-squared & 0.7517 & McFadden R-squared & 0.7402 \\
\hline
\end{tabular}


Notes: In the ordinary brackets below the parameter estimates are the corresponding z-statistics. In the square brackets, the associated marginal effects are given.

XXYYBAN = Percentage of the total foreign claims on country XX held by country YY's banks.

DEFXX = Government deficit-to-GDP of country XX.

XXGOVDEB = Government debt-to-GDP of country XX.

XXBANDEB $=$ Banks' debt-to-GDP of country XX

XXNFIDEB = Non-financial corporations' debt-to-GDP of country XX.

XXHOUDEB $=$ Households' debt-to-GDP of country XX

XXPUB $=$ Foreign bank's claims on government debt-to-GDP of country XX.

XXBAN = Foreign bank's claims on banks debt-to-GDP of country XX.

XXPRI = Foreign bank's claims on non-financial private debt-to-GDP of country XX.

INFXX = Inflation rate of country XX.

$\mathbf{U X X}=$ Unemployment rate of country XX

CACXX = Current-account-balance-to-GDP of country XX

RATXX $=$ Credit rating scale of country XX

XXLIQ = Overall outstanding amount of government domestic debt securities of country XX.

RISK = Global risk aversion indicator.

GR, IE, IT, PT and SP stand for Greece, Ireland, Italy, Portugal and Spain, respectively. 